\title{
The role of technical protocols and partnership engagement in developing a decision support framework for fisheries management
}

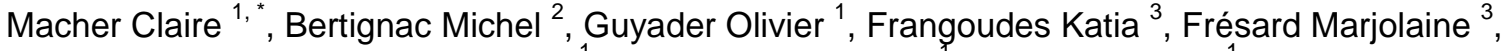 \\ Le Grand Christelle ${ }^{1}$, Merzéréaud Mathieu ${ }^{1}$, Thébaud Olivier ${ }^{1}$
}

${ }^{1}$ Ifremer, Univ Brest, CNRS, UMR 6308, AMURE, Unité d'Economie Maritime, IUEM, F-29280, Plouzane, France

2 Ifremer, Unité Sciences et Technologies Halieutiques, France

${ }^{3}$ Univ Brest, Ifremer, CNRS, UMR 6308, AMURE, IUEM, 29280, Plouzane, France

* Corresponding author : Claire Macher, email address : claire.macher@ifremer.fr

\begin{abstract}
:
In the context of the Common Fisheries Policy Reform, the implementation of multiannual management plans for fisheries and the annual quota negotiations between EU member states has generated a growing demand from stakeholders and managers for integrated advice that goes beyond the usual biological advice. This has led to the emergence of bio-economic tools and methods for the comparison of the biological, economic and social tradeoffs associated with alternative options for fisheries management. A Decision Support Framework (DSF) has been developed in this context, with the objective to tackle technical and methodological challenges to be able to provide bio-economic advices to support decision at national and European level. It is based on a partnership approach involving the fishing industry, managers and scientists and on technical protocols. We present the development of a partnership DSF within three local case studies, highlighting key challenges and lessons learnt regarding appropriateness and application of a DSF. The data processing methods and collaborative platform were pivotal for scoping out objectives and management options, and for aligning DSF outcomes with decision makers' needs and agendas. Definition of common standards and institutionalization of the use of partnership DSF are still required to operationalize the integrated advice process at national and European levels.
\end{abstract}

\section{Highlights}

- Reducing time to provide integrated advice is key for fisheries decision support. Data processing methods are key components of operational decision support. DSF should include transdisciplinary knowledge integration. Common standards for the use of the DSF would improve decision support. Institutionalizing the use of participatory DSF would improve decision making.

Keywords : Participatory approach, Stakeholder engagement, Decision-support, Bio-economic modelling, Fisheries management, Impact assessment 
35 The implementation of Ecosystem-Based Management (EBM), defined as "an integrated approach 36 that considers the entire ecosystem, including humans" (McLeod et al., 2005), and its application to 37 fisheries have driven a search for new tools and approaches to facilitate the integration of social and 38 environmental dimensions in decision making into an evidence-based policy approach. Among the 39 challenges of implementing marine ecosystem-based management, Leslie and McLeod (2007) 40 underline the need for tools to "better evaluate impacts of human activities on ecosystems and 41 trade-offs among objectives" and the need for research that is "more connected to management and 42 policy processes". They also argue for interdisciplinary development, communication and 43 participation of stakeholders. 
In Europe, the supra-national level creates a specific process for management where negotiation between member states plays an important role (Marchal et al., 2016). While scientific advice provided at European Union (EU) level is mainly biological advice, socio-economic dimensions are usually taken into account in the negotiation step.

In the context of the Common Fishery Policy (CFP) Reform (CEC, 2009), new regulations and balanced objectives between environmental, and socio-economic issues generated a growing demand for integrated scientific evaluations and impact assessments ${ }^{1}$ beyond the usual biological advice (see impact assessment groups at the Scientific Technical and Economic Committee for Fisheries (STECF) level https://stecf.jrc.ec.europa.eu/). This has led to re-examination of the decision-support for fisheries management. In the EU context, STECF initiated the development of an operational framework for impact assessment of management plans, including stakeholder engagement (Impact Assessment protocol, STECF 2010). The SOCIOEC European Project presented a framework for impact assessment including stakeholders at different steps in Malvarosa et al. (submitted). This should help supporting negotiations for fisheries management between member states at EU level and between stakeholders and decision makers at national and EU levels.

Maximum Sustainable Yield, established as the management target for all the stocks, were to be applied where possible in 2015 and at the latest in 2020, with a timetable depending on socioeconomic considerations. Scientific advice based on Maximum Sustainable Yield objectives are thus to be balanced in European negotiations to account for socio-economic and multi-specific issues during the decision-making process. To address such a growing demand and improve the European decision-making process, there is a need for the development of operational Decision Support Frameworks (DSF) designed to assess and compare the biological, economic and social trade-offs associated with management strategies and to highlight distributional issues between member states and/or fleet segments, thus providing information for decisions at the European supra-national level.

The need for integrated scientific assessment concerns alternative transition pathways to Maximum Sustainable Yield (MSY) objectives, as well as regional multiannual management plans for fisheries, landing obligations, or quota management that are other major issues addressed in the CFP reform.

While a large range of integrated bio-economic models have been developed in recent years to help environmental and resource management and have demonstrated their utility in impact assessment of scenarios at national, EU or international levels, their application for decision support still requires a great deal of time and resources (see Nielsen et al., 2017 for a review of fisheries model approaches and their operational use and STECF, 2015 for examples of applications in the EU management plan impact assessment context). Moving from applied bio-economic tools to effective decision-support frameworks, i.e., frameworks providing integrated advice addressing both biological and socio-economic issues, still means facing a number of technical and methodological challenges. The main challenges highlighted in the literature concern the appropriateness of tools and data used in impact evaluation for specific management questions (e.g., Plagányi, et al., 2014, Punt et al., 2016) and the requirement to involve stakeholders, scientists and decision makers to improve the use and usefulness of models for decision making (e.g., Reed, 2008). There has thus been a growing consensus on the value of stakeholder participation in fisheries management decision-support and decision-making processes (Leslie and McLeod, 2007, Berghöfer et al., 2008, Thébaud et al., 2014), following evidence from a broad range of contexts (e.g., Hartley and Robertson, 2006; Luyet et al., 2012, Mackinson et al., 2011 or Röckman et al., 2012). The move from biological advice towards more integrated scientific advice including socio-economic aspects, has also initiated a trend towards

\footnotetext{
${ }^{1}$ At European level, impact assessment conducted on new initiatives expected to have significant economic, social or environmental impacts makes up the DSF. It is defined as a "set of logical steps [] that prepares evidence for political decision-makers on the advantages and disadvantages of possible policy options by assessing their potential [economic, social and environmental] impacts" (EC, 2009, 2015). Impact assessment is thus not only about the implementation of evaluation tools, but also about the process by which the evaluation can be carried out.
} 
more involvement from stakeholders, with varied degrees and types of involvement in research, from simple consultation to stronger collaborations (Mackinson et al., 2011).

Among DSF used for fisheries management, the Management Strategy Evaluation (MSE) framework provides interesting examples and applications for comparing and selecting management strategies, particularly in South Africa, in the International Whaling Commission (IWC) or in Australia (e.g., Butterworth and Punt 1999 or Smith et al., 1999). MSE is widely acknowledged as the reference for assessing robustness of management strategies to uncertainty in observation, model and implementation. It has mainly been used in mono-specific contexts to address uncertainty issues rather than trade-offs between different dimensions, but is being extended for application in the Ecosystem Based Management Context (Fulton et al., 2014, Plagányi et al. 2014). Literature on MSE building from experience and on lessons learnt on its use for decision-making also indicate technical issues regarding data and model and the importance of stakeholder involvement in collaborative modelling (e.g., Punt et al., 2016).

These challenges need to be addressed at national and EU levels if decision-support frameworks are to provide integrated bio-economic advice within partnership approaches useful to stakeholders and managers.

Participatory modelling provided a first basis for greater engagement of stakeholders in the decisionsupport process. Voinov and Bousquet (2010) reviewed different types of approaches and the lessons learnt on both the social aspects of participation and the methodological aspects of modelling. They highlight that co-learning, transparency and the process of stakeholder engagement are essential. They also underline that processes included (or not included) in the models, assumptions and limits need to be made explicit to potential users of the results, and that models should be flexible and of a complexity adapted to the question, objectives and available data. These authors conclude that participatory modelling can assist decision-making and tackle the high complexity of socio-ecological systems and the difficulties of evaluating different options. The benefit of participatory modelling in fisheries management is also to facilitate and structure discussion, and to increase transparency and co-learning (Röckmann et al., 2012).

Participatory modelling has been developing approaches in recent years, favoured by incentives to engage stakeholders in research projects and management strategy evaluation approaches (Dutra et al., 2015). Development of DSF fully integrating scientific and empirical knowledge from the fishing industry, managers and scientists, beyond modelling questions to provide bio-economic assessment and highlight trade-offs from a multi-criteria perspective remain limited, however. Stakeholder and manager engagement should enable adequate scoping, implementation and knowledge integration in a partnership framework to support an evidence-based policy approach implemented through impact assessment procedures.

In this paper, we present the development and application of a partnership DSF able to provide bioeconomic advice for national and European decision support. By DSF, we refer to a process for the integration of existing data and knowledge (biological, socio-economic, scientific and empirical) to provide relevant information on potential trade-offs between alternative management options to support decisions. It thus covers technical issues and development of tools for integration and assessment but also issues related to the process itself (Bolman et al., 2018). The DSF is designed to assess the biological and socio-economic trade-offs of alternative transition schemes to $\mathrm{MSY}^{2}$ through management plans, Total Allowable Catches (TAC) and quotas, considered as major issues by

\footnotetext{
${ }^{2}$ MSY was defined as one of the main management objective in the European Fisheries policy. The question of fishing rights and transferable fishing concessions, largely debated during the CFP reform, was eventually left to each Member State's decision. The framework developed was applied in the CFP reform context to transition schemes to MSY however it was also used in other contexts to explore the trade-offs existing between different institutional arrangements regarding quota management (Bellanger et al, in press) or to explore impacts of scenarios to Maximum Economic Yield instead of the adopted MSY target in Guillen et al. (2013).
} 
stakeholders and managers. The aim of this paper is to highlight the role of technical protocols and partnership engagement in developing a DSF for fisheries management. The paper focuses on the phase of decision-support involving science ${ }^{3}$ to provide information on trade-offs between different management options for the decision-making process. It was not possible to address the effective use made of information from the decision-support process and its importance in the decisionmaking process within the scope of this paper.

The paper will first present the context of the Bio-Economic Partnership Working Group project (BEPWG) and the collaborative definition of the objectives of the DSF. The methods and tools developed as part of the DSF (including the partnership platform with the fishing industry, managers and scientists, the data processing methods and the bio-economic integrated model) will then be described. The protocol for the use of the DSF and results of its application to the impact assessment of the Multiannual Management Plan for South Western Waters, exploration of options in the Channel scallop fishery and management of the western Mediterranean hake fishery are presented in a fourth section. Lessons learnt from the development and application of the partnership DSF are finally discussed with regards to its usefulness and perspectives for improvement towards an institutionalization of its use.

\section{Collaborative definition of the DSF objectives}

\subsection{Context and case studies}

The BEPWG project was started in 2009 with the support of the French Directorate of Sea Fisheries and Aquaculture (DSFA) ${ }^{4}$. The project aims to develop the ability to provide bio-economic assessment of management strategies for decision support within a collaborative process associating scientists, the fishing industry and managers. The project brought together economists, biologists, social scientists and fishing industry representatives at local, national and regional sea levels with the DSFA. The fishing industry was represented by French Producer Organizations, local, regional and national fishers' organizations, and the European South West Waters Advisory Council.

A kick-off meeting was organized at national level in 2009 to discuss the common objectives, approach and establishment of the partnership platform. All decided (1) to adopt an approach able to answer real-world management problems-questions and (2) to organize this collaboration around regional case studies.

During this meeting, the need to develop a new DSF emerged and it was decided to base its development on three case studies chosen together (Fig. 1).

\footnotetext{
${ }^{3}$ In Europe, the decision-support process and the decision making process are separted processes.

${ }^{4}$ www.umr-amure.fr/pg_partenarial_bioeco.php
} 


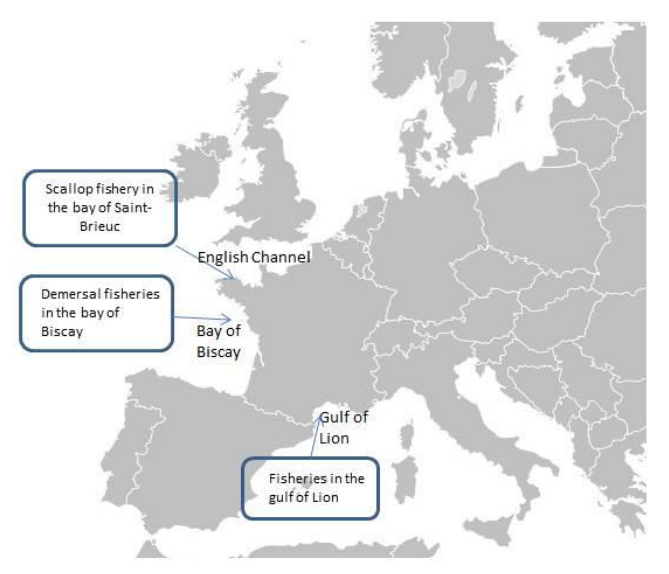

Figure 1: Case studies of development of the bio-economic partnership approach

The three case studies represent different contexts in terms of management, stakeholders, data and knowledge (see Table 1). All are strategic fisheries for France with high socio-economic stakes for their management. The scallop fishery in the Bay of Saint-Brieuc is located in the English Channel and illustrates a coastal stock assessed and managed under national and local regulations. The demersal fisheries in the Bay of Biscay are mixed fisheries characterized by high interactions between fleets targeting or by-catching the same stocks (technical interactions) and illustrates the European assessment and management context for shared stocks between member states. New multi-species management plans are under discussion between the European Parliament, Council and Commission, with strong demand from stakeholders and decision makers to explore alternative objectives and Harvest Control Rules (HCR) to design the new management plans. The hake fishery in the Mediterranean Gulf of Lion illustrates a stock shared between France and Spain, under Mediterranean management in a data-poor context. Demand for impact assessment by the General Fisheries Commission for the Mediterranean (GFCM) (a regional fisheries management organization of FAO) interacts with European objectives and implementation of multiannual management for fisheries in Europe. Hake is a key species in the Gulf of Lion fleet dynamic and its management is of high importance to stakeholders.

Table 1: Comparison of the three case studies where the bio-economic partnership decision-support framework was developed and implemented

\begin{tabular}{|c|c|c|c|}
\hline Fishery(ies) & $\begin{array}{l}\text { Bay of Saint-Brieuc scallop fishery } \\
\text { in the Channel }\end{array}$ & $\begin{array}{l}\text { Demersal fisheries in the Bay of } \\
\text { Biscay }\end{array}$ & $\begin{array}{l}\text { Hake fishery in the Mediterranean Gulf } \\
\text { of Lion }\end{array}$ \\
\hline $\begin{array}{l}\text { Socio-economic } \\
\text { Importance of } \\
\text { the fisheries }\end{array}$ & $\begin{array}{l}220 \text { French vessels } \\
480 \text { fishermen } \\
30 \text { million euros Gross Revenue }\end{array}$ & $\begin{array}{l}\sim 570 \text { French vessels } \\
1800 \text { fishermen } \\
200 \text { million euros Gross Revenue }\end{array}$ & $\begin{array}{l}\sim 180 \text { vessels (+ } 40 \text { Spanish vessels) } \\
520 \text { fishermen } \\
45 \text { million euros Gross Revenue }\end{array}$ \\
\hline Kind of Fisheries & Relatively mono-specific & $\begin{array}{l}\text { Mixed fishery with high technical } \\
\text { interactions }\end{array}$ & $\begin{array}{l}\text { Mixed fishery with interactions } \\
\text { between small scale fisheries and } \\
\text { trawlers and shared stocks with Spanish } \\
\text { fleets }\end{array}$ \\
\hline Main species & Scallop & $\begin{array}{l}\text { Northern hake, Bay of Biscay sole and } \\
\text { Nephrops, monkfish }\end{array}$ & Hake, anchovy, sardine, cephalopods \\
\hline Main fleets & Dredgers and trawlers & $\begin{array}{l}\text { French Nephrops and mixed bottom } \\
\text { trawlers and sole and mixed netters }\end{array}$ & $\begin{array}{l}\text { French Bottom trawlers and small } \\
\text { polyvalent or exclusive netters }\end{array}$ \\
\hline $\begin{array}{l}\text { Scale } \\
\text { governance }\end{array}$ & Local/regional management & $\begin{array}{l}\text { European Management at EU region: } \\
\text { South-western waters/ Bay of Biscay }\end{array}$ & $\begin{array}{lll}\text { European } & \text { and } & \text { international } \\
\text { Mediterranean } & \text { management context }\end{array}$ \\
\hline
\end{tabular}




\begin{tabular}{|c|c|c|c|}
\hline & & & $\begin{array}{l}\text { with local regulation based on regional } \\
\text { and local fishers organizations }\end{array}$ \\
\hline $\begin{array}{l}\text { Main actors of } \\
\text { the management }\end{array}$ & $\begin{array}{lr}\text { Local Fishery Committee, } & \text { French } \\
\text { administration, } & \text { Producer } \\
\text { Organization, } & \text { Regional } \\
\text { Administration } & \end{array}$ & $\begin{array}{l}\text { Europe, } \\
\text { Council, Producer Western Advisory } \\
\text { national and regional fishers } \\
\text { organizations, French administration }\end{array}$ & $\begin{array}{l}\text { Europe, General Fisheries Commission } \\
\text { for the Mediterranean (GFCM), } \\
\text { Regional and local fishers } \\
\text { organizations, French administration, } \\
\text { Producer Organizations }\end{array}$ \\
\hline $\begin{array}{l}\text { Management } \\
\text { context and } \\
\text { regulation }\end{array}$ & $\begin{array}{l}\text { Regulation based on: } \\
\text { - Limitations of the effort through } \\
\text { national non-transferable } \\
\text { licenses, limited fishing time } \\
\text { (days and hours) and temporal } \\
\text { closures + regulations on the } \\
\text { characteristics of the dredge. } \\
\text { - An indicative quota of scallops } \\
\text { decided based on scientific stock } \\
\text { evaluation to maintain a } \\
\text { sustainable exploitation. }\end{array}$ & $\begin{array}{l}\text { Management mainly relies on: } \\
\text { Total Allowable Catches set at } \\
\text { European levels and quotas. } \\
\text { License systems } \\
\text { Management plans: A recovery plan } \\
\text { implemented for hake in } 2004 \\
\text { (Council Regulation (EC) No } \\
811 / 2004 \text { of } 21 \text { April 2004). A multi- } \\
\text { annual management plan towards } \\
\text { MSY implemented for sole in the Bay } \\
\text { of Biscay in } 2006 \text { (Council Regulation } \\
\text { (EC) No } 388 / 2006 \text { of } 23 \text { February } \\
2006 \text { ) and a multi-annual multi- } \\
\text { species management plan to be } \\
\text { implemented within the CFP reform. }\end{array}$ & $\begin{array}{l}\text { Input control (temporary closures and } \\
\text { decommissioning schemes), GFCM } \\
\text { recommendations and perspectives for } \\
\text { multi-annual management plan towards } \\
\text { MSY. }\end{array}$ \\
\hline $\begin{array}{l}\text { Status of the } \\
\text { fishery }\end{array}$ & $\begin{array}{l}\text { Full-exploitation of the stock's } \\
\text { ensuring biological viability with } \\
\text { however high fluctuations } \\
\text { according to stock abundance and } \\
\text { environmental conditions. Good } \\
\text { economic performances which } \\
\text { could be improved by adjusting } \\
\text { fishing capacities to the stock } \\
\text { productivity and exploring the } \\
\text { impact of lengthening the fishing } \\
\text { season on prices. }\end{array}$ & $\begin{array}{l}\text { Over-exploited fishery within the } \\
\text { precautionary limits of Biomass } \\
\text { however (Fishing mortality for sole } \\
\text { should be reduced by more than } 30 \% \\
\text { in } 2016 \text { to FMSY, Hake is fully } \\
\text { exploited). Situation of characterized } \\
\text { over-capacity with rent } \\
\text { dissemination. }\end{array}$ & $\begin{array}{l}\text { High recruitment dependence and } \\
\text { strong overexploitation of the hake } \\
\text { stock that was assessed to be more } \\
\text { than ten times over the Fishing } \\
\text { mortality at MSY (Vasilakopoulos et al., } \\
\text { 2014). Economic profitability is highly } \\
\text { dependent on fuel price for trawlers. }\end{array}$ \\
\hline Data availability & $\begin{array}{l}\text { Stock assessment (national) and } \\
\text { production, activity and economic } \\
\text { data from the Fisheries Information } \\
\text { System }\end{array}$ & $\begin{array}{l}\text { Stock assessments (ICES) for some } \\
\text { stocks and production, activity and } \\
\text { economic data from the Fisheries } \\
\text { Information System }\end{array}$ & $\begin{array}{l}\text { Stock assessment for hake (GFCM- } \\
\text { STECF) and production, activity and } \\
\text { economic data from the Fisheries } \\
\text { Information System, with however } \\
\text { specific monitoring sampling programs } \\
\text { for small scale production to try to } \\
\text { overcome non reporting }\end{array}$ \\
\hline
\end{tabular}

\subsection{Identifying the DSF objectives}

190 A review of past and present demands for bio-economic assessment at national and EU levels was first made to identify areas of concern, type of management issues to be addressed and outputs expected. This review was mainly based on two sources: an analysis of the terms of reference of the STECF working groups on management plans and those of the requests of the French administration for fisheries.

This review was discussed and completed with stakeholders and managers during the first project meeting, where several issues were addressed:

- the main specifications expected from a DSF;

- the scenarios of interest the future DSF could be able to analyze;

- $\quad$ the main challenges to tackle.

The issue of management plans and transition schemes to MSY based on effort or TAC regulations was identified by all actors as a key question to be addressed, for which there still lacked operational DSFs providing assessment of biological and socio-economic trade-offs. 
The review and consultation of fishing industry and managers and experience from scientists of the project in decision-support tool development made it possible to build the main specifications of the DSF to advance towards providing bio-economic assessment for decision-making.

The specifications identified related to the following abilities:

- Being able to provide, in a short timeframe, the most complete and up-to-date description and modelling of fisheries dynamics in different case studies based on the most recently available data and knowledge.

- Designing a tool:

- able to account for the relevant dimensions (i.e., relevant species, fleets and spatio-temporal dimensions) and complexity (processes to be modelled) to assess the impact of concrete scenarios; the tool should be designed/implemented with regards to the set of management questions to address and the objectives, which will notably decide its spatial scale and timescale aspects;

- easy to parameterize and calibrate so that it can be used and updated in a relatively limited timeframe and be easily applicable to different fisheries (it should thus rely as much as possible on existing data and processes and interface easily with available databases);

- flexible enough to test new scenarios, include new processes or other possible developments required for management;

- capable of efficient and reliable calculation i.e., able to run a large number of simulations, including stochastic simulations, and/or solve optimization problems and produce outputs in a short time to quickly provide updated information for decision-making when needed.

- Providing appropriate indicators to assess the potential biological and socio-economic impact of scenarios and clear representation and visualization of trade-offs from a multi-criterion perspective. Choice of the indicators and their representation and visualization tools are key aspects for disseminating results and making them useful for decision-making.

- Providing transparent analysis on assumptions and limits: Clear assumptions and qualification of the results are important when providing knowledge for decision makers.

In addition to these objectives, another goal was to investigate a partnership approach that would move towards the production of integrated advice and promote its added value. The approach here refers to how to tackle the development and implementation of a DSF by identifying specifications required, developing a technical model and data-based solution, as well as developing partnership platforms for the evaluation of alternative management options in an operational approach to collaborative assessment.

Based on evidence from the literature, the aim of involving stakeholders and managers was to ensure that the tools developed respond to operational management problems and questions and to users' needs. The objectives were also to create conditions to integrate scientific and empirical knowledge within a trans-disciplinary approach and to identify potential needs for bio-economic advices and thus technical development to operate upstream of institutional demands. Creation of common knowledge on bio-economic modelling methods and outputs was also important, with the objective of enhancing the legitimacy of this type of approach and up-take of the results for decision-making.

\section{Methods developed as part of the partnership decision support framework}

In the project, the following three elements were developed to address the challenges related to building of a DSF for fisheries management in the European context as identified in 2.2: 
- The development of the partnership approach for the participation of fishing industry and managers in the process;

- The development of tools for data processing;

- The development of an integrated model IAM (Impact Assessment Model for fisheries management) with specifications designed to address the key challenges.

\subsection{Development of the partnership approach}

A major issue for addressing the challenges of operational impact assessment was the development of a partnership approach for the building and use of the DSF.

The partnership platform assembled scientists, stakeholders (representatives from the fishing industry) and managers with the objective of implementing operational and legitimated methods and tools to provide scientific knowledge for decision making, and to disseminate results (Fig. 2).

Figure 2: Partnership platform

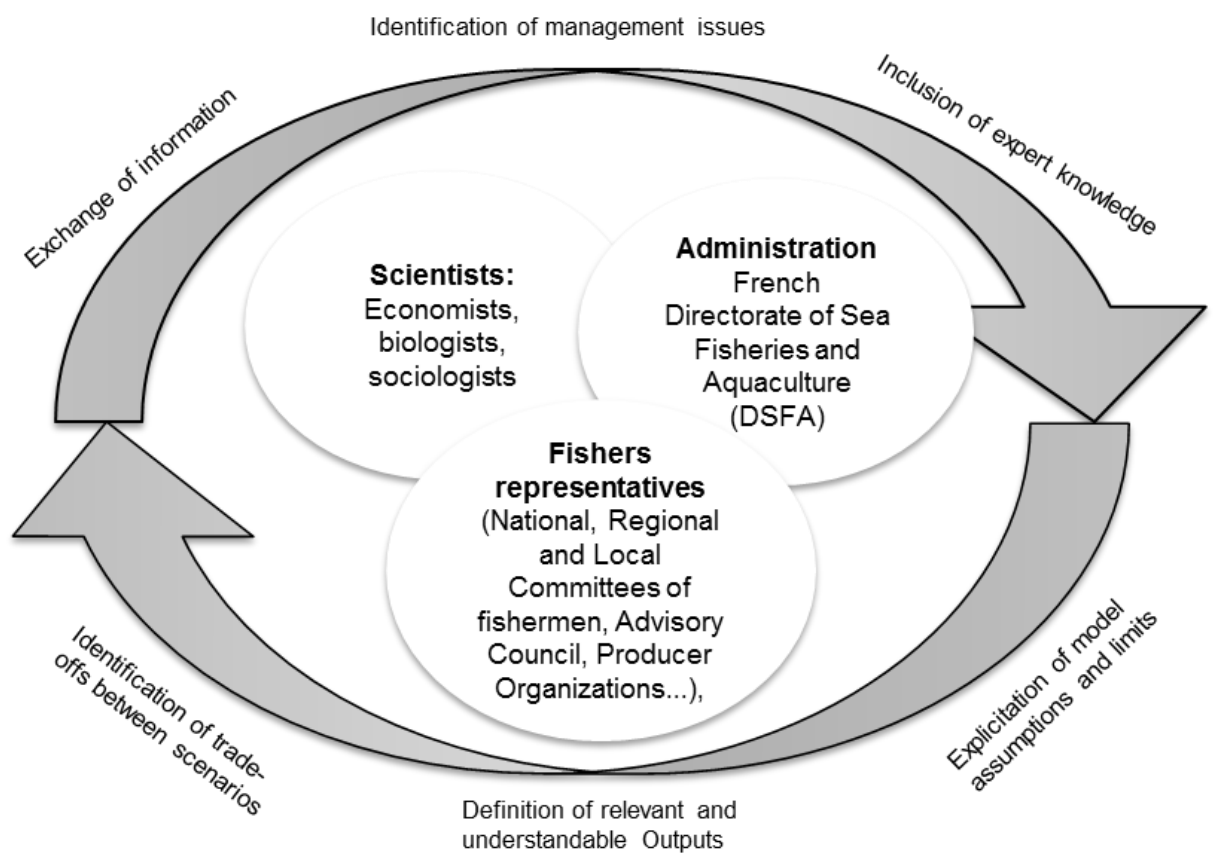

The partnership platform was initially designed to bring together the main actors of fisheries management and the fishing industry at the national level (main French producer organizations, national fisher's committee, South West Waters Advisory Council and French DSFA). At the second stage, it was extended to the main local and regional actors of the different case studies (local fishers' representatives in the scallop fishery, regional fishers' representatives of the LanguedocRoussillon region and main local fishers' representatives for the Gulf of Lion case study, and all the producer organizations of the Bay of Biscay).

The functioning of the platform was structured into working groups by case study and transversal groups working on methodological aspects interspersed with technical developments (Fig. 3). A preliminary description of the fishery and of the data sources was presented at the first set of case study working groups. The partners discussed and validated the data to be used and agreed on fishery representation (including aggregation level, typology and processes represented) based on their knowledge of past and present dynamics of the systems studied. Management issues in each studied area and prospective scenarios of interest to be tested and explored were defined in 
partnership. A second set of working groups was organized after a period dedicated to model development, parameterization and impact assessment of scenarios. Methods, assumptions and first results of the management scenarios were presented and discussed among partners. Quantitative outputs on possible trade-offs were complemented in some cases with expert knowledge, particularly regarding behaviours. Output indicators and their modes of representation were also discussed. Transversal working groups were held in parallel to validate the methodological work done on each case study and discuss methodological points. This working-group based approach enabled discussion and knowledge sharing with fishing industry experts at different stages of the project.

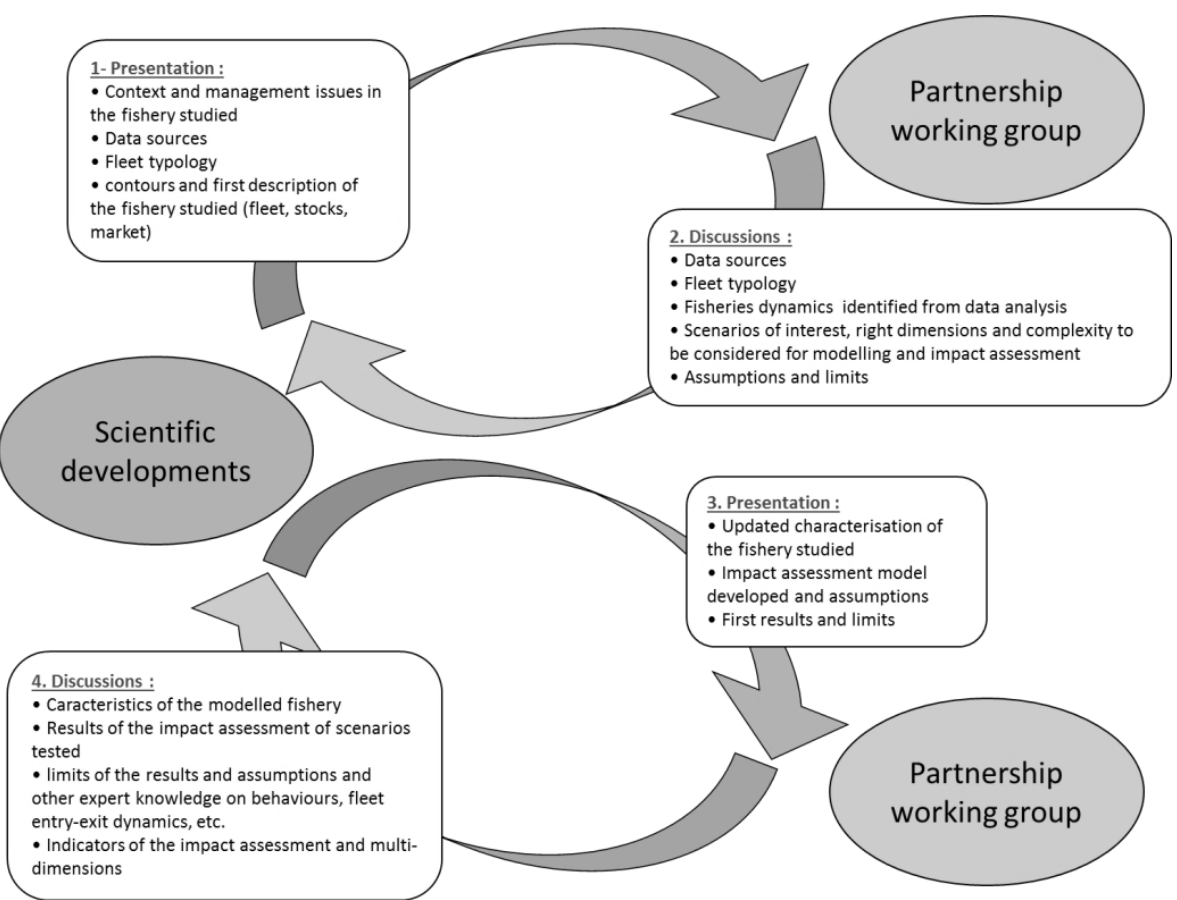

Figure 3. Participatory process developed

\subsection{Tools for data processing and standardized fisheries descriptions}

A major challenge identified by the participants is the ability to use the most up-to-date data efficiently in order to base management on the best available information. This should be achievable quickly, as decision support should generally be conducted within a limited time frame. The deadlines set for the impact assessment of multiannual management plans by the STECF, on behalf of the European Commission, provide a good illustration: the time dedicated to the definition of Terms of Reference and provision of an assessment was 2 months for model calibration, simulation and results analysis.

Operational description and modelling of fisheries dynamics requires a good knowledge of stocks, fleets and market dynamics based on the most recent data. Data processing and analyses are among the most time-consuming tasks and more efforts should be dedicated to their optimization. In practice, the main challenge is to be able to address a new case study quickly. This involves building a representation of the bio-economic system and parameterizing it with the latest stock assessments 
$\mathrm{R}^{5}$ data-processing methods were specifically developed to extract and analyze data from the Fisheries Information System (FIS) of Ifremer, which is an innovative network gathering and linking fisheries data on resources and uses (http://sih.ifremer.fr/). Data series on vessels' technical characteristics, strategies, effort and landings and economic performances are available and provide validated information to research programs and to advisory support services at Ifremer. Some of the data are compiled within the Data Collection Framework (Commission Regulation EC No 665/2008 of 14 July 2008). The stable structure of the database and availability of disaggregated data provided the opportunity to develop generic routines based on R scripts with the following objectives:

1. Identify and characterize the biological and economic components of the fishery concerned by the regulation under evaluation; i.e., define the contours of the fishery(ies) studied and the dimensions of the model (number of fleets, set of species concerned etc.). This is based on routines able to select a subset of vessels according to various selection criteria such as vessels fishing in a certain area, landing above a given tonnage of a particular species or using a particular gear ${ }^{6}$.

2. Extract the available data regarding catches, landings, fishing effort, vessel characteristics, fish prices and fishing costs for these vessels.

3. Create ad hoc typology of vessels at appropriate level of disaggregation to observe the potential trade-offs.

4. Calculate indicators used for the description of past and recent dynamics of the fishery.

5. Compile indicators into input files for the calibration of the impact assessment tool.

Figure 4 details the method developed to provide operational description of fisheries studied.

\footnotetext{
${ }^{5}$ R project - https://www.r-project.org/

${ }^{6}$ An initial set of selection criteria was coded to address the most frequent management questions reviewed in national and European requests: fishing management plans towards MSY for a set of species, management plans on particular gears as in the Mediterranean regulation, or territorial management issues for vessels fishing in a particular area (sea approach) or fishing from a particular region (land approach). Criteria are flexible to be adapted for new issues.
} 


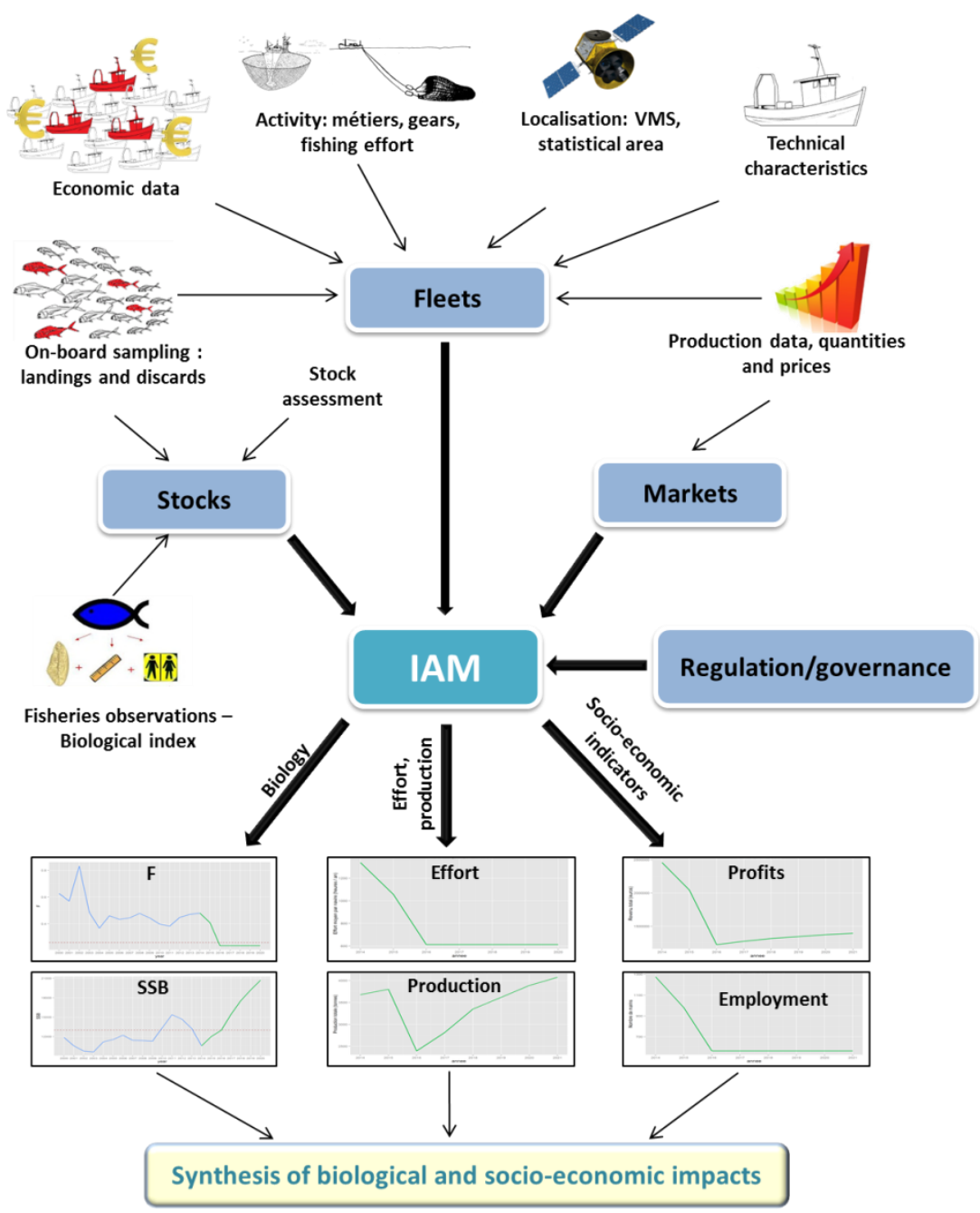

Figure 4. Operational Data Processing Methods

Data-processing methods developed produce two kinds of outputs: (i) Descriptive sheets including a set of updated tables and figures automatically built from R and LaTeX codes based on the databases. These sheets describe the technical characteristics, activity, production or economic performances of the fleets identified in the fishery or the variability of supply and price of the species landed in the fishery compared with the national market. They were used as a basis to share and complete a common description of the fishery dynamics with stakeholders and managers. (ii) Input parameter files per fleet or vessel and species to calibrate the impact assessment model. The codes developed to calculate the input parameters from databases have improved the process by testing and standardizing this step and making it repeatable, thus avoiding potential mistakes.

\subsection{A bio-economic operating model for biological and socioeconomic assessment of scenarios}

One important point for modelling was to develop a tool flexible enough to implement or modify options at different scales and easily identify new control variables while working in a limited timeframe. Two other features also had to be considered: (i) the simulation tool had to rely as much as possible on regularly-collected data and include internal calibration methods, and (ii) the coding language needed to use widely-used coding languages, computing performances and the possibility for post-analysis web simulations and visualization of outputs. 
The bio-economic Impact Assessment Model (IAM) developed has the same basis as other bioeconomic models developed at EU level, such as FLBEIA (Garcia et al., 2013, in press), SIMFISH (Barteling et al., 2015) and FISHRENT (Salz et al., 2011) or BEMTOOL (Rossetto et al., 2015). IAM was designed to perform quantitative multi-criteria analysis of various management scenarios and address the key challenges identified in the project's specification phase. The model is stochastic, and can include uncertainties on recruitment and prices of outputs. It combines different time steps according to the processes modelled: it has annual time steps for fleet dynamics and annual or quarterly time steps for biological dynamics. It is multi-fleet or multi-vessel, multi-species and multimetier. The model is applied to regional case studies but no explicit spatialization of effort is taken into account as spatial issues were not considered essential for exploring MSY scenarios. According to existing knowledge, species can be represented through age-structured stock dynamics with an analytical assessment or global production model. For species for which biological dynamics are well known, production functions are based on the Baranov equation. Catches of other main species for which little is known about the stock dynamics are included through linear functions of fishing effort and landings per unit of effort (other functional forms are also possible).

The usual main economic dynamics considered in bio-economic models can be included, such as market dynamics and price elasticity, fleet dynamics, catchability increase through investment or technical creeping, or short-term behaviours. Several assumptions concerning impacts of scenarios on gross revenue are possible, including reallocation of effort assumptions. Several vessel behaviours regarding TAC consumption and choke species can be tested including the lowest/highest quota behaviours used in ICES $(2017)^{7}$ or the maximum profit behaviour under TAC constraints or reallocation of the effort of the fleet among metiers according to habits and/or profitability. When used for simulation, the model generates full timeseries datasets and compiles several statistics on the impact of scenarios in terms of stock biological status, vessel economic performance, vessel number, employment in the fishery and crew salaries. The model assesses impacts in the short, medium and long terms. It provides multi-criteria analysis, analyses of the transition phases in terms of biological, social or economic viability and analysis of impact distribution between fleets and between owners and crew. The model can also be used to perform cost-benefit analysis of scenarios compared with the status quo in terms of net present value. Properties of the model make implementation of scenarios possible at any time or dimension. Options such as consideration of external factors (fuel cost increase) or alternative options of effort reallocation can be tested. The program can also be used for both simulation (scenario exploration) and optimization (e.g., to find the fleet structure that maximizes rent).

Compared with existing bio-economic models (reviewed in Nielsen et al., 2017), one of the main originalities of this model is that it is designed and developed to directly use data from stock assessments and input files created from the operational data processing methods developed within the project. Input variables for the model correspond to outputs of stock assessment and a limited number of transversal and economic indicators calculated at the required level of aggregation from the Fisheries Information System or from European data collected under the Data Collection Framework regulation. The parameterization process was partly automated by linking the model to the Ifremer Fisheries Information System databases. The model can thus be easily updated with the latest data series available for any particular fishery. Internal calibration methods based on existing input data have also been implemented to facilitate parameterization and calibration. The model

\footnotetext{
${ }^{7}$ Lowest quota behaviours assumes that fleets stop fishing when the first quota is reached (assumption of full observation of the landing obligation), highest quota behaviour assumes that fleets keep fishing until the last quota is consumed and discards over-consumption of quotas
} 
thus allocates fishing mortality by metier and fleet metier according to catch-at-age by metier and landings by fleet and metier.

The modular basis chosen allows development flexibility and facilitates addition of extra functions (Fig. 5). Modules can be connected, disconnected, replaced by other modules or coupled with other models. Each module corresponds to an equation or a small number of equations describing a process and works with a set of inputs and a declaration of outputs. Intermediate variables created can be managed through scenarios or injected into other modules or models.

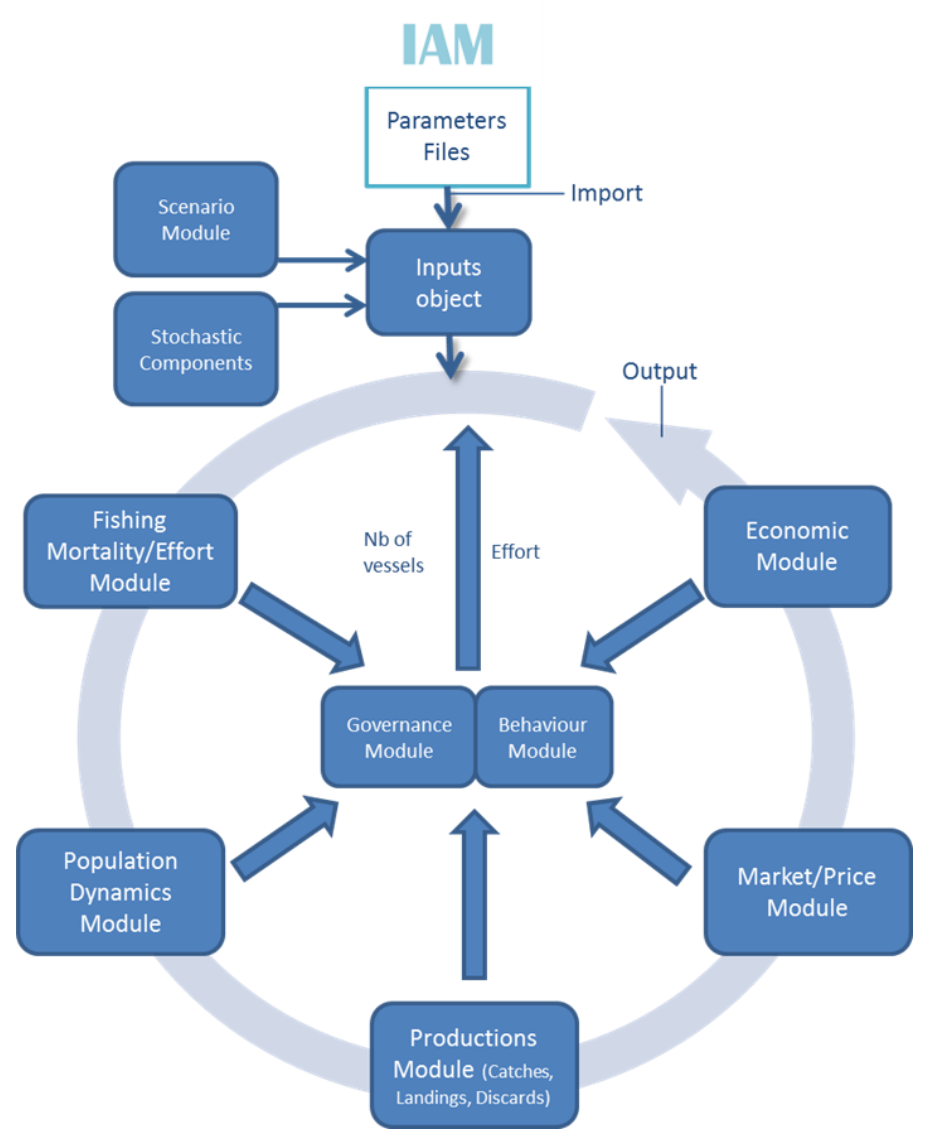

Figure 5. Modular structure of the IAM model

The model computing language combines $\mathrm{R}$ (for the user interface, data handling and output presentations) and $\mathrm{C}++$ (for all the calculation modules). It was expected that the choice of a commonly used language that is useable or at least understandable by non-programmer specialists would allow better buying-in. The language and technical specifications of the model made it possible to create an "IAM" R package with compiled C++ code and to develop web applications working with $\mathrm{C}++$ compiled code.

The model was developed and used to assess the impacts of various management scenarios discussed in the context of the CFP Reform: variation of exploitation pattern/adoption of selective devices (Raveau et al., 2012), alternative transition to MSY based on variation of fishing activity (fishing effort in time), variation of fishing capacity (number of vessels), TAC and quota and HCR, sensitivity and transition to reference points (Guillen et al., 2013, Macher et al., 2011), comparison of alternative institutional arrangements - quota pooling implemented by producer organizations in France - versus individual transferable quotas system as discussed in the CFP reform (Bellanger et al., in press). It was used for the impact assessment of the Bay of Biscay management plan at STECF level 
(STECF, 2011, 2015). A full description of the model's equations is provided in these papers and in

\subsection{DSF application protocol}

The bio-economic partnership DSF was implemented in the three case studies following the same protocol for partnership impact assessment. The protocol documents a standardized operational method identifying resources, methods, and actors to be involved at each step to perform impact assessment of scenarios for decision-support as well as expected outcomes regarding the partnership approach. It is based on the steps given in table 2 .

Table 2: Steps of the protocol for partnership impact assessment of scenarios, actors involved, methods and outcomes

\begin{tabular}{|c|c|c|c|}
\hline Steps of the protocol & Actors involved & Methods & Outcomes \\
\hline $\begin{array}{l}\text { 1.Identification and engagement } \\
\text { of key actors of the fishery }\end{array}$ & $\begin{array}{l}\text { Scientists with } \\
\text { stakeholders }\end{array}$ & $\begin{array}{l}\text { Analysis of institutional context } \\
\text { +interviews of key actors }\end{array}$ & Stakeholders engagement \\
\hline $\begin{array}{l}\text { 2.Identification of the institutional } \\
\text { context and the management } \\
\text { issues }\end{array}$ & $\begin{array}{l}\text { Scientists, } \\
\text { stakeholders, } \\
\text { managers }\end{array}$ & $\begin{array}{l}\text { Analysis of institutional context } \\
\text { and information sharing with } \\
\text { key actors interviews or focus } \\
\text { groups }\end{array}$ & $\begin{array}{l}\text { Management issues and context in each } \\
\text { case study }\end{array}$ \\
\hline $\begin{array}{l}\text { 3.Delimitation of the contours of } \\
\text { the fishery studied in terms of } \\
\text { stocks, fleets, markets concerned } \\
\text { according to key issues }\end{array}$ & $\begin{array}{l}\text { Scientists, } \\
\text { stakeholders, } \\
\text { managers }\end{array}$ & $\begin{array}{l}\text { Reference reports on stock } \\
\text { assessment and fisheries from } \\
\text { ICES, STECF or GFCM } \\
\text { Inventory of available data } \\
\text { Analysis of fleets and species }\end{array}$ & $\begin{array}{l}\text { Criteria of selection for species, fleets } \\
\text { and geographic area to be considered in } \\
\text { each case studies }\end{array}$ \\
\hline $\begin{array}{l}\text { 4.Selection of appropriate fleet } \\
\text { typology/ segmentation according } \\
\text { to question or co-creation of ad } \\
\text { hoc typology where needed to } \\
\text { highlight trade-offs }\end{array}$ & $\begin{array}{l}\text { Scientists, } \\
\text { stakeholders }\end{array}$ & Focus groups & Shared typology with stakeholders \\
\hline $\begin{array}{l}\text { 5. Extraction of data, analysis of } \\
\text { sampling, consolidation of } \\
\text { segmentation/ clusters }\end{array}$ & Scientists & $\begin{array}{l}\text { Data processing methods } \\
\text { developed based on existing } \\
\text { data bases }\end{array}$ & $\begin{array}{l}\text { Data base by case study gathering all } \\
\text { the data available to describe and } \\
\text { model dynamics }\end{array}$ \\
\hline $\begin{array}{l}\text { 6.Description of fishery ex-post } \\
\text { dynamics }\end{array}$ & Scientists & $\begin{array}{lc}\text { Methods developed } & \text { for } \\
\text { indicators calculation } & \end{array}$ & $\begin{array}{l}\text { Automatic generated PDF documents } \\
\text { describing each fishery studied in terms } \\
\text { of fleet's characteristics, activity, } \\
\text { production, profitability, market and } \\
\text { prices, stock status with most updated } \\
\text { data series }\end{array}$ \\
\hline $\begin{array}{l}\text { 7.Parameterization and calibration } \\
\text { of IAM }\end{array}$ & Scientists & $\begin{array}{l}\text { Methods developed for } \\
\text { indicators calculation }\end{array}$ & Calibrated model \\
\hline $\begin{array}{l}\text { 8.Definition with partners of } \\
\text { scenarios to explore and } \\
\text { assumptions }\end{array}$ & $\begin{array}{l}\text { Scientists, } \\
\text { stakeholders, } \\
\text { managers }\end{array}$ & Focus groups & Description of scenarios to be tested \\
\hline 9.Simulation of scenarios & Scientists & $\begin{array}{l}\text { Bio-economic } \\
\text { developed - IAM }\end{array}$ & $\begin{array}{l}\text { Results in terms of impacts of scenarios } \\
\text { on stocks, fleet's profitability, } \\
\text { employment and wages }\end{array}$ \\
\hline $\begin{array}{l}\text { 10.Production and visualization of } \\
\text { results }\end{array}$ & $\begin{array}{l}\text { Scientists with } \\
\text { stakeholders } \\
\text { and managers to }\end{array}$ & $\begin{array}{l}\text { Data processing } \begin{array}{r}\text { and } \\
\text { visualization }\end{array} \text { methods }\end{array}$ & $\begin{array}{l}\text { Diverse figures and tables based on } \\
\text { quantitative results or qualitative } \\
\text { visualization highlighting trade-offs }\end{array}$ \\
\hline
\end{tabular}




\begin{tabular}{|l|l|l|l|}
\hline & $\begin{array}{l}\text { define outputs } \\
\text { visualization } \\
\text { format }\end{array}$ & developed on IAM outputs & from a multi-criteria perspective \\
\hline $\begin{array}{l}\text { 11.Discussion of results, limits and } \\
\text { additional knowledge on impact } \\
\text { assessment of scenarios with } \\
\text { partners }\end{array}$ & $\begin{array}{l}\text { Scientists, } \\
\text { stakeholders, } \\
\text { managers }\end{array}$ & $\begin{array}{l}\text { Qualitative assessment of } \\
\text { scenarios }\end{array}$ & $\begin{array}{l}\text { Qualitative knowledge to inform on } \\
\text { potential effort reallocation + new } \\
\text { scenarios tested to simulate various } \\
\text { option of reallocation based on } \\
\text { stakeholders knowledge }\end{array}$ \\
\hline
\end{tabular}

431

432

433

434

The protocol follows the main steps identified for bio-economic impact assessment of scenarios as described in STECF (2017).

\subsection{Application to the three case studies}

This section presents the main results on lessons learnt from the application work. They address relevance and usefulness of the partnership DSF developed and applied with regards to objectives identified. For some issues this intersects with the five dimensions framework developed by Boleman et al. (2018) to evaluate the appropriateness of a given Decision Support System (DSS) according to identification and engagement of stakeholders, utilization of the DSS, objective setting, data and outcomes of the DSS.

The same protocol was applied to each of the case studies with, nevertheless, some adaptations to the available data and scenarios tested. Data processing methods were developed based on existing databases and applied in the different case studies, including the data-poor Mediterranean context. It was possible to adapt methods to data availability and formats. The main results are presented in table 3, following the main steps of the protocol developed. In particular, the table presents the stakeholders engaged in the framework, scenarios selected, type of results obtained and effective use of the DSF in a decision-support context. The role of technical protocols and partnership engagement in developing a DSF for fisheries management was highlighted by the implementation of the protocol in the three case studies.

Protocols developed were proven to tackle the main objectives identified regarding the ability to provide bio-economic assessment of scenarios of interest within a collaborative process, over a short time and using up-to-date data. Time and human resources needed to provide integrated assessment of options were low thanks to the data processing and calibration methods developed. The main core of the tools was developed during the first two years of the project. The key step requiring time and human resources (including stakeholders and managers) was the definition of the fisheries concerned by management options in terms of selection of fleets and species to be modelled. For calibrated applications, running bio-economic assessment of new scenarios was made possible within one-week working groups, thus providing the tools and methods to go beyond the usual biological advice. For scenarios already tested, real time simulations were made possible even if these were not tested in the project. New regional applications still require time and resources, mainly to develop the collaborative approach at the case-study level to co-define the system to represent and the management issues to be addressed.

Data processing methods were considered crucial in making the process more operational and transparent, to provide the most complete and updated representation of the fishery. They greatly increased the ability to provide results in a relatively short timeframe and the standardization and repeatability of methods for impact assessment, thus improving the decision-support process. Application of the processing methods and visualization of the description of the fisheries system enabled stakeholders to validate the scientific data used. It also led to the inclusion of their expert knowledge in the description. Resulting up-dated bio-economic description of the fisheries was a 
useful joint product of the approach. Specifications chosen for the model and its ability to adapt to different case studies and management issues were also tested in the application to the case studies. In the Bay of Saint-Brieuc, the management issues at stake led to ecological processes being taken into account in the biological model and to the inclusion of control processes. In the Bay of Biscay, the framework was first applied to the sole fishery, then to the demersal fishery context including mixed sole, Nephrops and hake fisheries, which required the data and model dimensions to be updated. The recent move from MSY targets to MSY ranges in the European management context and political agenda for impact assessment also created conditions in which the ability of the model to adjust the management variables could be tested. This led to substantial modifications to the modelling framework that were completed within a limited period. The partnership approach that had been developed and the knowledge of this case study were useful in this context to adapt the framework and use the background information co-created over the years. Fisher behaviour assumptions were also adjusted to account for expert knowledge on possible effort reallocation (table 3).

Table 3: Results of the implementation of the partnership decision support framework in the three case studies

\begin{tabular}{|c|c|c|c|}
\hline Fishery(ies) & $\begin{array}{l}\text { Bay of Saint-Brieuc scallop } \\
\text { fishery in the Channel }\end{array}$ & $\begin{array}{l}\text { Demersal fisheries in the Bay } \\
\text { of Biscay }\end{array}$ & $\begin{array}{l}\text { Hake fishery in the } \\
\text { Mediterranean Gulf of Lion }\end{array}$ \\
\hline $\begin{array}{l}\text { Key actors involved in the } \\
\text { partnership }\end{array}$ & $\begin{array}{ll}\text { Local } & \text { fishermen } \\
\text { representatives (from } 2 \text { local } \\
\text { committees) and French } \\
\text { Administration }\end{array}$ & $\begin{array}{l}\text { European South-Western } \\
\text { Advisory Council, Producers } \\
\text { Organizations, national } \\
\text { fishermen Committee, French } \\
\text { Administration }\end{array}$ & $\begin{array}{lr}\text { Local } & \text { fishermen } \\
\text { representatives and French } \\
\text { Administration }\end{array}$ \\
\hline $\begin{array}{l}\text { Modes of identification of the } \\
\text { institutional context and the } \\
\text { management issues }\end{array}$ & $\begin{array}{l}\text { Partnership and surveys with } \\
\text { fishermen }\end{array}$ & Partnership -focus groups & $\begin{array}{l}\text { Partnership and surveys with } \\
\text { fishermen }\end{array}$ \\
\hline $\begin{array}{l}\text { Management issues } \\
\text { highlighted in partnership }\end{array}$ & $\begin{array}{l}\text { Effort regulation and control, } \\
\text { impact of the invasive species } \\
\text { Crepidula Fornicata on Scallops } \\
\text { harvesting }\end{array}$ & $\begin{array}{l}\text { Management plans towards } \\
\text { MSY and quota }\end{array}$ & $\begin{array}{l}\text { MSY transition and temporal } \\
\text { closures }\end{array}$ \\
\hline Model specificities & $\begin{array}{l}\text { Includes processes to account } \\
\text { for impact on stock dynamic of } \\
\text { the invasive species and } \\
\text { control }\end{array}$ & Standard version & Standard version \\
\hline Scenarios tested & $\begin{array}{l}\text { Variations of the number of } \\
\text { vessels and / or variations of } \\
\text { the number of days at sea }\end{array}$ & $\begin{array}{l}\text { MSY transition pathways for } \\
\text { sole with adjustment of fishing } \\
\text { effort or capacity : } \\
\text { - Scenarios of gradual } \\
\text { decrease in fishing } \\
\text { mortality until reaching } \\
\text { the MSY with different } \\
\text { timetables; } \\
\text { Scenarios of constant } \\
\text { Total Allowable Catches } \\
\text { (TACs) for sole } \\
\text { Scenarios of adjustment } \\
\text { of the capacities } \\
\text { according to various } \\
\text { weighting factors } \\
\text { (correlated with } \\
\text { contribution to fishing } \\
\text { mortality) and various } \\
\text { objectives (maximizing } \\
\text { employment or profit) }\end{array}$ & $\begin{array}{l}\text { MSY transition pathways for } \\
\text { hake with adjustment of fishing } \\
\text { effort or capacity and temporal } \\
\text { closures: } \\
\text { - Scenario of one month } \\
\text { closure of the fishery for } \\
\text { the French hake trawlers; } \\
\text { - Scenario of transition to } \\
\text { MSY for hake with a } \\
\text { gradual decrease in the } \\
\text { number of days at sea per } \\
\text { vessel per fleet, or in the } \\
\text { number of vessels per fleet } \\
\text { by } 5 \%, 10 \%, 15 \% \text { per year }\end{array}$ \\
\hline Description of the fishery & $\begin{array}{l}\text { Partnership validation of the } \\
\text { fishery description elaborated } \\
\text { by using existing data and } \\
\text { typology. }\end{array}$ & $\begin{array}{l}\text { New typology co-created in } \\
\text { partnership } \\
\text { Partnership validation of the } \\
\text { fishery description using } \\
\text { existing data and ad hoc } \\
\text { typology }\end{array}$ & $\begin{array}{l}\text { Partnership validation of the } \\
\text { fishery description elaborated } \\
\text { by using existing data and the } \\
\text { new typology developed for } \\
\text { Mediterranean } \\
\text { fisheries }\end{array}$ \\
\hline
\end{tabular}




\begin{tabular}{|c|c|c|c|}
\hline Types of results & $\begin{array}{l}\text { Fishery description }+ \text { bio- } \\
\text { economic assessment of the } \\
\text { scenarios selected }^{8}\end{array}$ & $\begin{array}{l}\text { Fishery description }++ \text { bio- } \\
\text { economic assessment of the } \\
\text { scenarios selected }+ \\
\text { quantitative and qualitative } \\
\text { analysis with the stakeholders } \\
\text { of the fishing reallocation } \\
\text { possibilities according to } \\
\text { fishing possibilities } \\
\text { availabilities and technical } \\
\text { constraints. }\end{array}$ & $\begin{array}{l}\text { Fishery description }+ \text { bio- } \\
\text { economic assessment of the } \\
\text { scenarios selected }\end{array}$ \\
\hline Use of the DSF & Local - project & $\begin{array}{l}\text { National requests and STECF } \\
(2011,2015)\end{array}$ & $\begin{array}{lrr}\text { National requests } & + \\
\text { presentations to GFCM and } \\
\begin{array}{l}\text { Mediterranean } \\
\text { Council }\end{array}\end{array}$ \\
\hline Status of application & none & $\begin{array}{l}\text { Pursuit of developments and } \\
\text { partnership for multi-annual } \\
\text { management plan in the } \\
\text { western waters }\end{array}$ & Current update of the model \\
\hline $\begin{array}{l}\text { Significance of the demand for } \\
\text { impact assessment }\end{array}$ & $\begin{array}{l}\text { Low at the local and national } \\
\text { level for a resource already } \\
\text { highly regulated at the local } \\
\text { level }\end{array}$ & $\begin{array}{l}\text { High at European and national } \\
\text { level in the context of } \\
\text { management plans and quota } \\
\text { negotiation }\end{array}$ & $\begin{array}{l}\text { Medium at national level for } \\
\text { Mediterranean management } \\
\text { plans and at Mediterranean } \\
\text { level in GFCM and STECF } \\
\text { context }\end{array}$ \\
\hline
\end{tabular}

Development of the partnership approach in the three case studies was found to have an important added-value in creating suitable conditions for sharing and integrating scientific and empirical knowledge from stakeholders. This was particularly useful for building a common representation of the fisheries concerned by the management system in question. This also helped to better align scientific development timelines with the political agenda and needs of impact assessment, particularly in the Bay of Biscay, where there was a strong demand related to the management plan context. The collaborative approach also permitted the joint definition of prospective scenarios and alternative options to explore. In the Bay of Biscay case study, the partnership approach was further developed and provided interesting collaborations in terms of typology co-creation, management options and complementarity of the results with qualitative information on effort reallocation. Alternative strategies for transition to MSY have been proposed by the fishing industry, including different weighting rules for the decrease of fleet capacity or fishing effort according to alternative objectives of profit maximization, employment maximization or effort reduction minimization. Another benefit was that participation may help to narrow the definition of model dimensions to be incorporated (number of fleets, species, time steps, spatial resolution) and to validate the fisheries dynamics and behaviours to include. Participation of the fishing industry and managers was also important in results interpretation and qualification. Finally, qualitative translation of quantitative results or exploration of the ways to visualize results is important for improving the usefulness and use of results by decision-makers. Over time, the process also developed a common language and vastly improved the capacities and skills of the fishing industry and managers to understand bioeconomic approaches, assumptions and results, thus increasing their potential trust and buy-in for decision making. The adoption of a case-study problem-based approach oriented towards pragmatic management questions was found to be a key factor for stakeholder's commitment.

The main differences observed between the case studies concerned the effective demand for and use of the developed DSF to inform decision. The demand in the different case studies was strongly linked to the existence of a political agenda for new regulations and to the obligation at EU level for a new regulation to correspond with the impact assessment process.

\footnotetext{
${ }^{8}$ See Macher et al. (2011) for details on bio-economic assessment of scenarios in each case studies and synthetic figures representing trade-offs between biological, and socio-economic dimensions in alternative scenarios also represented in supplementary material 2.
} 
In the Bay of Saint-Brieuc, the bio-economic results were presented to stakeholders and to DFSA but remained unused for management. This was related to the national context where the demand for such assessment was low, given the context of an already strongly managed fishery and its good bioeconomic performances. This was also linked to the relative homogeneity of the fishery and the management in place, where distributional issues between fleet segments were not at stake. In the Gulf of Lion, the outputs of the simulation of transition to MSY for hake were used for national requests and presented at the GFCM and at a MEDAC (Mediterranean Advisory Council) workshop. The approach is currently being updated in Seaviews, a Belmont Forum research project. It will be used for impact assessment of multiannual management plans currently being defined, which highlight important issues regarding interactions between small-scale fisheries and trawlers, the shared stocks/area between Spain and France and the economic viability of trawlers. In the Bay of Biscay, the partnership was first developed in the context of the implementation of a management plan for sole that initiated demands from stakeholders and managers for information and comparison among different pathways and time schedules towards MSY. The results were used for sole in 2011 (STECF, 2011) on the basis of recommendations made during a scoping meeting and stakeholder consultations (STECF, 2010). The prospect of the implementation of the multiannual management plan provided in the new CFP and the need to support quota decisions then generated high demand and interest from managers and stakeholders for scientific bases to help in designing a plan and HCR in the high valued demersal fisheries of the Bay of Biscay. The partnership was pursued in the demersal fisheries case study up to 2010 in relation to the Regional Advisory Council. The partnership platform was operational for 6 years with a dynamic closely linked to stakeholders' demands, needs and motivation to participate in the partnership, the administration's decision to provide support for the process and the capacity of scientists to meet the demand and provide knowledge. This resulted in a time schedule matching the political agenda and the constraints of data availability. The approach and tools developed were used in this context in 2015 to conduct an impact assessment for the multiannual management of the south-western waters, including the Bay of Biscay (STECF, 2015).

During this period, however, the governance of the partnership evolved from scientific leadership (2009-2011) to co-leadership between scientists and stakeholders (2012-2014) and then to stakeholder leadership in the most recent years (2015-2016), thus moving to the decision-making step. The partnership approach, which developed towards knowledge integration to highlight potential trade-offs between alternative management strategies, was useful in providing impact assessment of proposed scenarios at the STECF level. The absence of clear governance and institutionalization of the platform was however a weakness for moving forward towards more integration between decision support and the decision-making process.

\section{Discussion}

Development of integrated approaches in practical decision contexts led to the need to identify and tackle the challenges of operational decision support in terms of both technical developments for bio-economic scenario modelling and the engagement of fishing industry's representatives and managers. The bio-economic partnership approach developed with the fishing industry and managers contributed greatly to design an operational DSF able to provide impact assessment of alternative management strategies highlighting trade-offs between biological, social and economic dimensions including distributional issues between fleet segments. Methods for data processing are now used on a regular basis for description of fleet characteristics based on the most recent data. Their use is becoming both easy and rapid. The bio-economic impact assessment model is used to explore alternative management scenarios and TAC options for national requests or in the STECF impact assessment process, and up-dating of existing regional applications of the model can be done within a short time. 
It was not possible to assess the use of the DSF results in decisions in the European context of negotiation, which is a major limitation preventing the assessment of DSF outcomes for management and its efficiency in contributing towards management objectives. At EU level, separation between decision-support and decision-making processes and the important process of negotiation increase the importance and need to examine the information flow between the two spheres: between science and policy, as underlined in Soomai (2017). Documentation of this flow and in particular of the use made in the decision process of integrated scientific advice, produced for example at STECF level, would be an interesting research direction. This would contribute to improving the decisionsupport process. Opportunities for the mobility of scientists to decision-making institutions (transdiscipline mobility) also contribute towards this objective. Exploring the use made from scientific adive would nevertheless imply transparency about the true role of science in the decision-making process and making decisions themselves more transparent.

578

579

580

581

582

583

584

585

586

587

588

589

590

591

592

593

594

595

596

597

598

599

600

601

602

603

604

605

606

607

608

609

610

611

612

613

614

615

616

The approach developed nevertheless constitutes a step forward in the partnership approach to decision support in Europe and proposes an innovative collaborative process to build and implement a shared DSF that has been used in the decision-support process. The collaborative partnership platform that assembled scientists from several disciplines, representatives of the fishing industry and managers was pivotal for scoping objectives and management options, sharing management issues and fishery status, identifying needs for knowledge and the scenarios to explore, and cocreating knowledge for impact assessment to support decision making. The problem-oriented approach strongly related to management issues guaranteed stakeholder interest and alignment of the technical developments with real-world questions. It made it possible to stay close to operational management problems and to guarantee the usefulness of the DSF outcomes by co-defining scenarios to test and integrating empirical and scientific knowledge in the impact assessment of options. It also developed mutual trust and understanding that should ensure usefulness and use of the resulting science-based advice. The work done in partnership enabled capacity building and improvement of knowledge and skills of each group and tended to add legitimacy to methods developed in this context, as also underlined by Hartley and Robertson (2006), Bergöfer et al. (2008) or Röckman et al. (2017), who highlight the efficiency of partnership in increasing the salience and credibility of science. The new CFP, with multiannual management plans and the increasing demand for integrated advice in TAC negotiations caused a shift from biological advice towards more integrated advice including socio-economic considerations. In consequence, it created strong incentives for the fisheries industry to become actors of the decision-support process. More generally, this can also explain the increasing role of science in the decision process and increasing participation of the fishing industry in fisheries research and management decision making.

The time needed to update data and calibrate models, even if shortened, remains a key step in the process, which requires time and resources. This is particularly so for unexplored case studies where expertise on the definition and issues of the fishery are still unknown and remains a major challenge for the improvement of decision-support processes. Perspectives of improvements exist in the organization and integration of knowledge into updated databases and in the development of preprocessing tools for these databases. Recent improvements in the observation of fisheries systems (resources, uses and governance) now offer perspectives for technical improvements regarding the structuring of bio-economic databases and the development of calibration methods based on existing data. This could make the use and updating of complex integrated models possible and could help in providing decision support within the limited timeframe required by management issues. The framework developed and applied to French case studies highlights that there is room for sharing and improving common protocols and methods among developers in a multi-model approach, which has become a reality at EU level. The initial idea to develop one unique bio-economic tool for impact assessment failed, as model operation requires skills and practice and the best models remain the ones developed by those needing to apply them. In this context, development of common methods 
for input parameter calculation based on shared databases integrating biological and economic data and made available to scientists (at EU level for example) would be a key step for improvement and model consistency. This would also question the choice of fisher behaviours assumptions which can significantly modify economic consequences. This creates possibilities for interested groups to use the DSF to advance their own interests by using alternative assumptions impacting the results. Common visualization procedures for outputs would also make multi-model output more consistent and comparable. An interesting perspective is therefore to define standardized protocols for model utilisation (setting scenarios and options to be tested for recurrent assessment and agreeing upon assumptions for simulations and output indicators expected) and common standards for the use and visualisation of outputs provided to managers. Development of flexible/adaptable tools able to adopt the right level of complexity appeared to be also one of the criteria for successful and effective interaction with stakeholders. The project demonstrated the importance of pursuing efforts to improve interactions between scientists and stakeholders. Technical advances and new modelling tools and interfaces should provide new opportunities for stakeholder knowledge to be used in the co-creation and scaling with scientists of modelling systems with coherent spatial and temporal dimensions in line with practical management issues. This should also help in providing technical support for visualization and communication of results and would contribute to enhancing scientific salience. On this issue, strong decision makers (end-users) engagement, particularly in the development phase should ensure the appropriateness of the DSF developed for their needs and favour buy-in for decision making. In the three case studies, the development of the DSF lacked clear definition by the end-users of the information used for decision making. A better understanding of the need of decision support and of the way to present and compute results for a better uptake of science in decisions is a major issue.

Stronger involvement of decision-makers in the decision-support process would also improve the ability to overcome threats created by uncertain political agendas. This point was not addressed explicitly in the literature previously cited (Voinov and Bousquet, 2010; Voinov et al., 2016; Hamilton and al., 2015), although it appears to be of particular importance. In Europe, the decision process changed to a co-decision process between the Parliament, Council and Commission. This has particularly challenged and delayed the implementation of the new multiannual management plan defined in the new CFP. As soon as the debate on the co-decision for management plan was closed, impact assessment processes were implemented by the STECF with short deadlines defined by the political agenda to provide results (and a major change from an MSY target to ranges of MSY). This prevented proper implementation of the impact assessment process. The scoping step was mainly technical due to time constraints, and the engagement of stakeholders in the process, as defined in the STECF protocol for impact assessment, was not fully observed. The major issues addressed were linked to the important shift in fisheries management from a unique MSY target to a range of MSY. This provides an example of how the political agenda can threaten the process and the difficulty of shaping a decision-support platform in this context. A solution enabling the political agenda to be better taken into account was included in the partnership approach designed to make agenda of each party transparent and take better account of their constraints.

Active involvement of decision makers in the DSF design and process should also prevent the use of simple proxies instead of more integrated and detailed approaches that require more resources and time. Time for scientific development and knowledge integration are thus challenging the quality of knowledge used for decision-making in a context of an evidence-based approach to environmental management. In this respect, scientists should devote more effort to demonstrating the added value of integrated assessments with adequate complexity and the bias of simple proxies. This should make it possible to improve alignment of the scientific implementation timeline with the political agenda, as well as to improve the information flow between decision support and the decisionmaking process. At EU level, the need for economic assessment of the impact of alternative quota options for annual negotiations for quotas is clearly expressed. The partnership approach tends to increase trust and to legitimate integrated approaches highlighting short and long term and 
biological and socio-economic trade-offs, but there is a need to improve how the pro and cons of alternative methods are weighed up. Another matter of concern is the sensitivity of results to assumptions, which should also be further explored to improve the robustness of the results obtained. The management strategy evaluation framework provides an integrated approach to tackle such uncertainty issues, although it needs to take better account of the importance of institutional arrangements and fisher's behaviour in the operating and the implementation models (Fulton et al., 2014; Bellanger et al., in press). Among other approaches to operationalize Ecosystem Based Management, the co-viability approach can also provide an interesting perspective to provide advice reconciling ecological, economic and social dimensions (see Doyen et al., 2017 and Gourguet et al., 2013). Stakeholder and manager engagement in this kind of approach are currently under study.

Beyond technical or methodological abilities to provide integrated and shared bio-economic advice for decisions, is the institutional question of framework application. The challenges highlighted, relating to technical issues and to the participatory process, were handled by the protocol and tools developed. However, the DSF developed was opportunistically used in the Bay of Biscay and Mediterranean case study without any institutional framework. The partnership governance of the platform was developed under changing leaderships, progressively shifting from a scientific to a stakeholder leadership where the role of science was not clear anymore. This highlighted the need for a clear definition of governance of this kind of partnership decision-support platform, and management of the temptation to engage in the decision-support process to influence decisions. The role of each of the different parties in the decision-support process should be explicitly defined and was identified as a key issue for the success of this process, as also underlined in Röckman et al. (2017) or Reed (2008) who call for institutionalized stakeholder's participation to overcome limitations. This also pointed out the need to clearly separate decision support from decision-making processes in the context of stakeholder engagement in research to guarantee the overall benefit of the partnership decision-support process and avoid the perception that stakeholders' involvement in decision support is equivalent to a consultation for decision making. The partnership developed in the Bay of Biscay thus experienced unclear situations in the implementation of the impact assessment process for the management plan. Engagement of stakeholders in the bio-economic partnership approach to develop the methods, provide alternative options and knowledge on their consequences was not fully differentiated from the formal scoping meeting planned in the impact assessment process. The approach demonstrated that such confusion in the roles of stakeholders and decision makers should be strictly avoided, highlighting the need for well-structured decisionsupport processes and clear defined governance of the partnership.

A clearer definition of the governance and leadership of partnership platforms and of the role each partner (decision makers, scientists, and other actors) in the triangle of interaction explored in Röckman et al. (2015) are thus required to avoid potential instrumentalization of science in the decision process. Leadership of the decision-support platform and of the dynamics of the partnership in the long term were also identified as key questions. While building a long-term partnership is beneficial to the co-creation and integration of expert knowledge, maintaining the dynamics of this partnership and of the engagement of each of the parties can become problematic and needs to be planned for in advance. Inputs from social science on the process and lessons learnt from a larger range of case studies would help further develop practical recommendations in this area.

\section{Conclusion}

The innovative partnership DSF developed and applied in different case studies provides a relevant contribution to the operational bio-economic decision support in fisheries. Identification of the challenges and opportunities highlights the added value of integrating knowledge from scientists, stakeholders and managers. It also pointed out the continued difficultly of aligning scientific time 
needed with the political timelines, which generates serious threats to the scientific quality of advice compared with more simplistic and generic approaches. Data-processing methods based on fully integrated bio-economic databases, flexibility of bio-economic model, and the partnership approach were seminal in contributing towards the operational production of bio-economic advice. Further potential developments still need to be considered in order to extend the use and appropriateness of this type of partnership DSF in support to environmental management. These concern the development of integrated databases stable for the development of data processing methods and the definition of common standards (assumptions), scenarios and options and output indicators visualization) to operate models in different regions. They also relate to the need to institutionalize the use of this type of DSF to increase transparency of decision support and the role of scientific advice in decisions.

\section{Acknowledgements}

This work was supported by the French Directorate of Sea Fisheries and Aquaculture (DSFA) from 2009 to 2015, by the EU FP7 SOCIOEC project (Grant no. 289192) from 2012 to 2015 and by the "Laboratoire d'Excellence" Labex Mer (ANR-10-LABX-19) under the program "Investissements d'Avenir". This financial support is gratefully acknowledged. Authors would like to thank Guilhem Marre for providing the initial version of fig. 4 and the anonymous reviewers for their valuable comments that contributed greatly to improving previous versions of this work.

\section{References}

Bartelings, H., Hamon, K. G., Berkenhagen, J. \& Buisman, F. C., 2015. Bio-economic modelling for marine spatial planning application in North Sea shrimp and flatfish fisheries. Environmental Modelling \& Software. 74, 156-172.

Bellanger, M., Macher, C., Merzéréaud, M., Guyader, O., Le Grand, C., 2018. Investigating trade-offs in alternative catch-share systems: an individual-based bio-economic model applied to the Bay of Biscay solefishery. Can. J. Fish. Aquat. Sci Publisher's official version: http://doi.org/10.1139/cjfas2017-0075. http://archimer.ifremer.fr/doc/00416/52779/ Open Access version : 1-17

Berghöfer, A., Wittmer, H., Rauschmayer,F., 2008. Stakeholder participation in ecosystem-based approaches to fisheries management: A synthesis from European research projects. Marine Policy. $32,243-253$.

Boleman, B., Jak, R.G., van Hoof, L. 2018. Unravelling the myth-The use of Decisions Support Systems in marine management. Marine Policy, 87. 241-249.

Butterworth, D.S. and Punt, A.E. (1999) Experiences in the evaluation and implementation of management procedures. ICES Journal of Marine Science 56, 985-998.

CEC - Commission of the European Communities, 2009. Green Paper. Reform of the Common

Fisheries Policy. $\operatorname{COM}(2009) 163$ final. $27 \quad$ p.
lex.europa.eu/LexUriServ/LexUriServ.do?uri=COM:2009:0163:FIN:EN:PDF.

Council Regulation (EC) No 811/2004 of 21 April 2004 establishing measures for the recovery of the northern hake stock. http://data.europa.eu/eli/reg/2004/811/2011-01-01.

Council Regulation (EC) No 388/2006 of 23 February 2006 establishing a multiannual plan for the sustainable exploitation of the stock of sole in the Bay of Biscay. http://data.europa.eu/eli/reg/2006/388/oj. 

P-Y., Jennings S., Little L.R., Macher C., Mills D. J., Noussair A., Pascoe S., Pereau J-C., Sanz N., Schwarz A-M., Smith T., Thebaud O., 2017. Ecoviability for ecosystem-based fisheries management. Fish And Fisheries, 18(6), 1056-1072. http://doi.org/10.1111/faf.12224

Dutra Leo, X. C., Thebaud, O., Boschetti, F., Smith, A. D. M., Dichmont, C. M., 2015. Key issues and drivers affecting coastal and marine resource decisions: Participatory management strategy evaluation to support adaptive management. Ocean \& Coastal Management, 116, 382-395. http://dx.doi.org/10.1016/i.ocecoaman.2015.08.011.

European Commission. 2009. Impact assessement Guidelines. SEC(2009) 92.50 p. http://ec.europa.eu/smart-regulation/impact/commission guidelines/docs/iag 2009 en.pdf.

European Commission. 2015. Better Regulation Guidelines. SWD(2015) 111 final. 91 p. http://ec.europa.eu/smart-regulation/guidelines/docs/swd br guidelines en.pdf.

Fulton EA., Smith ADM., Smith DC., Johnson P. 2014. An Integrated Approach Is Needed for Ecosystem Based Fisheries Management: Insights from Ecosystem-Level Management Strategy Evaluation. PLoS ONE 9(1): e84242. https://doi.org/10.1371/journal.pone.0084242

Garcia, D., Prellezo, R., Sampedro, P., Da- Rocha, J., Cerviño, S., Castro, J., Gutierrez, M. \& Garcia (in press) Bioeconomic multi-stock reference points as a tool for overcoming the drawbacks of the landing obligation. ICES Journal of Marine Science.

Garcia, D., Urtizberea, A., Diez, G., Gil, J. \& Marchal, P., 2013. Bio-economic management strategy evaluation of deepwater stocks using the FLBEIA model. Aquatic Living Resources. 26, 365-379.

Gourguet S., Macher C., Doyen L., Thebaud O., Bertignac M., Guyader O. , 2013. Managing mixed fisheries for bio-economic viability. Fisheries Research, 140, 46-62. Publisher's official version : http://doi.org/10.1016/j.fishres.2012.12.005 http://archimer.ifremer.fr/doc/00129/23999/

Guillen, J., Macher, C., Merzereaud, M., Bertignac, M., Fifas, S., Guyader, O., 2013. Estimating MSY and $\mathrm{MEY}$ in multi-species and multi-fleet fisheries, consequences and limits: an application to the Bay of Biscay mixed fishery . Marine Policy . 40, 64-74 . http://doi.org/10.1016/i.marpol.2012.12.029.

Hamilton, S.H., Guillaume, J., ElSawah, S., Jakeman, A.J. and Pierce, S.A. 2015. Integrated assessment and modelling: overview and synthesis of salient dimensions. Environmental Modelling and Software. 64, 215-229.

Hartley, T. W. and Robertson, R.A. 2006. Stakeholder Engagement, Cooperative Fisheries Research 171.

ICES (2017). Report of the Working Group on Mixed Fish-eries Advice (WGMIXFISH-ADVICE). 22-26 May 2017 Copenhagen, Denmark. ICES/CIEM - International Council for the Exploration of the Sea/Conseil International pour l'Exploration de la Mer, Ref. ICES CM 2017/ACOM:18, 128p.http://archimer.ifremer.fr/doc/00416/52711/.

Leslie, H.M. and McLeod, K. L. 2007. Confronting the challenges of implementing marine ecosystembased management. Frontiers in Ecology and the Environment. 5, 540-548. http://dx.doi.org/10.1890/060093. participation in environmental projects. Journal of Environmental Management. 111,213-219. 
[en ligne] "Groupe de travail Partenarial pour la construction d'outils bio-économiques d'aide à la décision pour l'aménagement des pêcheries", Publications électroniques Amure, Série Rapports R21-2011, 44 p. http://www.umr-amure.fr/electro_rapports_amure/R_21_2011.pdf.

Mackinson, S., Wilson, D.C., Galiay, P., Deas, B. 2011. Engaging stakeholders in fisheries and marine research. Marine Policy. 35(1), 18-24.

Malvarosa, L., Murillas, A., Lehuta, S., Nielsen, R., Macher, C., Goti-Aralucea, L., Motova, A., Doering, R., Haraldson, G., Accadia, P., Hamon, K., Bastardie, F., Maravelias, C.D., Mardle, S., Thogersen, T., Sustainability Impact Assessment (SIA) in fisheries. Implementation in EU fishing regions. Submitted. Marine Policy.

Marchal P., Andersen J. L., Aranda M., Fitzpatrick M., Goti L., Guyader O., Haraldsson G., Hatcher A., Hegland T.J., Le Floc h P., Macher C., Malvarosa L., Maravelias C. D., Mardle S., Murillas A., Nielsen J. R., Sabatella R., Smith A. D. M., Stokes K., Thoegersen T., Ulrich C. (2016). A comparative review of fisheries management experiences in the European Union and in other countries worldwide: Iceland, Australia, and New Zealand. Fish And Fisheries, 17(3), 803-824. Publisher's official version : http://doi.org/10.1111/faf.12147 , Open Access version http://archimer.ifremer.fr/doc/00312/42305/

McLeod, K. L., Lubchenco, J., Palumbi, S. R., Rosenberg, A. A. 2005. Scientific Consensus Statement on Marine Ecosystem-Based Management. Signed by 221 academic scientists and policy experts with relevant expertise and published by the Communication Partnership for Science and the Sea. 21 pp.

Merzereaud, M., Macher, C., Bertignac, M., Fresard, M., Le Grand, C., Guyader, O., Daures, F., Fifas, S. (2011). Description of the Impact Assessment bio-economic Model for fisheries management (IAM). https://w3.ifremer.fr/archimer/doc/00067/17808/15337.pdf .

Nielsen, J R., Thunberg, E., Holland, D. S, Schmidt, J. O, Fulton, B., Bastardie, F., Punt, A.E., Allen, I., Bartelings, H., Bertignac, M., Bethke, E., Bossier, S., Buckworth, R., Carpenter, G., Christensen, A., Christensen, V., Da-Rocha, J. M., Deng, R., Dichmont, C. M., Doering, R., Esteban, A., Fernandes, J. A., Frost, H., Garcia, D., Gasche, L., Gascuel, D., Gourguet, S., Groeneveld, R. A , Guillen, J., Guyader, O., Hamon, K. G., Hoff, A., Horbowy, J., Hutton, T., Lehuta, S., Little, L R., Lleonart, J., Macher, C., Mackinson, S., Mahevas, S., Marchal, P., Mato-Amboage, R., Mapstone , B., Mathieu, F., Palacz, A., Pascoe, S., Paulrud, A., Plaganyi, E., Prellezo, R., van Putten, E I., Quaas, M., Ravn-Jonsen, L., Sanchez, S., Simons, S., Thébaud, O., Tomczak, M. T , Ulrich, C., van Dijk, D., Vermard,Y., Voss, R., Waldo, S. 2017. Integrated ecological-economic fisheries models-Evaluation, review and challenges for implementation. Fish and Fisheries. 2017, 1-29. DOI: 10.1111/faf.12232.

Plagányi, É.E., Punt, A.E., Hillary, R., Morello, E.B., Thébaud, O., Hutton, T., Pillans, R.D., Thorson, J.T., Fulton, E.A., Smith, A.D. and Smith, F., 2014. Multispecies fisheries management and conservation: tactical applications using models of intermediate complexity. Fish and Fisheries. 15(1), 1-22.

Punt, A.E., Butterworth, D.S., Moor, C.L., De Oliveira, J.A. and Haddon, M., 2016. Management strategy evaluation: best practices. Fish and Fisheries. 17(2), 303-334.

Raveau A., Macher C., Mehault S., Merzereaud M., Le Grand C., Guyader O., Bertignac M., Fifas S., Guillen G. J. (2012). A bio-economic analysis of experimental selective devices in the Norway lobster (Nephrops norvegicus) fishery in the Bay of Biscay. Aquatic Living Resources. 25(3), 215-229 . Publisher's official version : http://doi.org/10.1051/alr/2012035 , Open Access version : http://archimer.ifremer.fr/doc/00110/22135/.

Reed, M.S. 2008. Stakeholder participation for environmental management: a literature review. Biological conservation. 141 (10), 2417-2431. 

management: the importance of transparency and rules for participation, in Conservation in the Anthropocene Ocean. Ed. by P. Levin, and M. Poe. Forthcoming, 2017.

Röckmann, C., Ulrich, C. Dreyer, M., Bell, E., Borodzicz, E., Haapasaari, P., Hauge, KH., Howell, D., Mäntyniemi, S., Miller, D., Tserpes, G., Pastoors, M., 2012. The added value of participatory modelling in fisheries management - what has been learnt? Marine Policy. 36(5), 1072-1085, ISSN 0308-597X, http://dx.doi.org/10.1016/j.marpol.2012.02.027. (http://www.sciencedirect.com/science/article/pii/S0308597X12000462).

Röckmann, C., van Leeuwen, J., Goldsborough, D., Kraan, M., Piet, G., 2015. The interaction triangle as a tool for understanding stakeholder interactions in marine ecosystem based management. Marine Policy. 52, 155-162, ISSN 0308-597X, http://dx.doi.org/10.1016/j.marpol.2014.10.019.

(http://www.sciencedirect.com/science/article/pii/S0308597X14002814).

Rossetto, M., Bitetto, I., Spedicato, M. T., Lembo, G., Gambino, M., Accadia, P., Melià, P. 2015. Multicriteria decision-making for fisheries management: a case study of Mediterranean demersal fisheries. Marine Policy 53, 83-93. doi: 10.1016/j.marpol.2014.11.006

Salz P., Buisman, E., Frost, H., Accadia, P., Prellezo, R. and Soma, K. 2011. FISHRENT, Bio-economic simulation and optimisation model for fisheries. 74 p.LEI Report 2011-024 ISBN/EAN: 978-90-8615514-9.

Smith, A.D.M., Sainsbury, K.J. and Stevens, R.A. 1999. Implementing effective fisheries-management systems - management strategy evaluation and the Australian partnership approach. ICES Journal of Marine Science 56, 967-979.

Soomai, S., 2017. Understanding the science-policy interface: Case studies on the role of information in fisheries management. Environmental Science \& Policy. 72, 65-75.

STECF (Scientific Technical and Economic Committee for Fisheries), 1-5 February 2010. Report of the STECF Study Group on the development of protocols for Multi-annual Plan Impact Assessments (SGMOS 10-1). In: Simmonds, J. (Ed.), Germany, Hamburg 48 p. http://stecf.jrc.ec.europa.eu/c/document library/get file?uuid=2f15be27-bf41-4515-98d7f09bdb30387a\&groupld=43805.

STECF (Scientific, Technical and Economic Committee for Fisheries), 2011. Impact Assessment of Bay of Biscay sole (STECF-11-01). European Commission, Ref. Publications Office of the European Union, Luxembourg, EUR 24814 EN - 2011, 41p.http://archimer.ifremer.fr/doc/00051/16187/.

STECF (Scientific, Technical and Economic Committee for Fisheries), 2015. Multiannual management plans SWW and NWW ( STECF - 15 - 08 ). CSTEP/STECF, Ref. EUR XXXX EN, JR C XXXX, 80p.http://archimer.ifremer.fr/doc/00274/38555/.

STECF (Scientific, Technical and Economic Committee for Fisheries), 2017. Bio-Economic Methodology (EWG-17-05); Publications Office of the European Union, Luxembourg; EUR 28359EN; doi:10.2760/759034.

Thebaud, O., Innes, J., Doyen, L., Lample, M., Macher, C., Mahevas, S., Mullon, C., Planque, B., Quaas, M., Smith, T., Vermard, Y. (2014). Building ecological-economic models and scenarios of marine resource systems: Workshop report. Marine Policy. 43, 382-386. http://dx.doi.org/10.1016/i.marpol.2013.05.010

Vasilakopoulos, P., Maravelias, C.D., Tserpes, G., The Alarming Decline of Mediterranean Fish Stocks. Current Biology. 24 (14), 1643-1648. https://doi.org/10.1016/i.cub.2014.05.070.

Voinov, A and Bousquet, F. 2010. Modelling with stakeholders. Environmental Modelling \& Software. $25,1268-1281$. 
Voinov, A., Kolagani, N., McCall, M. K., Glynn, P. D., Kragt, M. E., Ostermann, F. O., Pierce, S. A., Ramu, P., 2016. Modelling with stakeholders - Next generation, Environmental Modelling \& Software. 77, 196-220, ISSN 1364-8152, http://dx.doi.org/10.1016/j.envsoft.2015.11.016.

This supplementary material provides an updated version of the description of IAM based on the working document by Merzéréaud et al. (2011) ${ }^{9}$. This document describes the modular structure and the main equations of the model. It details input parameters and calculated variables. Parameterization and implementation of simulations within an R environment are also briefly described.

Note that an adaptation of the description of IAM based on Merzéraud et al., 2011 is provided in its individual-based format as online supplementary materials in Bellanger et al., $2018^{10}$.

\section{Notations}

IAM is a bio-economic model in discrete time, multi-fleet or multi-vessel, multi-métier, and multispecies with "age" components for the biological part, and "commercial category" components for the economic part. The parameters of the model can thus be broken down according to 7 distinct definition indices which are described in the table below:

\begin{tabular}{|l|l|}
\hline Symbols & Description \\
\hline$t$ & Time \\
\hline Forv & Fleet or vessel \\
\hline$m$ & métier \\
\hline $\mathrm{m}$ & Métier) \\
\hline$e$ & species \\
\hline
\end{tabular}

\footnotetext{
${ }^{9}$ Merzéréaud, M., Macher, C., Bertignac, C., Frésard, M., Le Grand, C., Guyader, O., Daurès, F., and Fifas, S. 2011. Description of the Impact Assessment bio-economic Model for fisheries management (IAM), Amure Electronic Publications, Working Papers Series D-29-2011, 19 pp. Available at: http://www.umramure.fr/electro_doc_amure/D_29_2011.pdf.

${ }^{10}$ Bellanger Manuel, Macher Claire, Merzéréaud Mathieu, Guyader Olivier, Le Grand Christelle Investigating trade-offs in alternative catch-share systems: an individual-based bio-economic model applied to the Bay of Biscay sole fishery. Canadian Journal of Fisheries and Aquatic Sciences IN PRESS. Publisher's official version : http://doi.org/10.1139/cjfas-2017-0075, Open Access version : http://archimer.ifremer.fr/doc/00416/52779/
} 


\begin{tabular}{|l|l|}
\hline$i_{e}$ & age (depends on species) \\
\hline$c_{e}$ & category (depends on species) \\
\hline
\end{tabular}

Table 1 - Definition of indices used in the model description.

These indices determine the structuration of $R$ inputs objects. These objects are formatted multidimensional matrices, including all the information needed by the model to both perform calculations of output indicators, but also to ensure the robustness of implementations.

This specific formatting, common to the input and output data, facilitates processing that can be applied to them. Several types of population dynamics can be applied; they are for the moment 3 in number, and are the following:

- population dynamics of type XSA (by default, annual and structured by age ex: Sole 8ab)

- population dynamics of type SS3 (quarterly and structured by age and cohort, ex Hake 8ab ${ }^{11}$ )

- SPiCT population dynamics (annual Pella-Tomlinson model)

We can add to these three options the possibility of not considering biological dynamics. The productions will then be calculated on the basis of landings per unit of effort, considered or not constant over time.

The implementation of each of these dynamics will require a set of specific parameters.

This document presents the model equations corresponding to the case of a population dynamics of type XSA.

\section{Modules description}

\section{Fishing mortality and discards survival module}

This module is divided into two sub-modules. The first sub-module carries out the splitting of total mortality rate into fleets, using their ratio in catch or landings at age. The second sub-module calculates a catchability coefficient which is used in the simulation to relate the control variable « effort » to the fishing mortality applied to the stock.

\subsection{Sub-module Fishing mortality allocation}

\section{- Initial parameters}

\begin{tabular}{|l|l|}
\hline Notation & Description \\
\hline
\end{tabular}

\footnotetext{
${ }^{11}$ Structuration by length is translated in to structuration by age based on length-age key.
} 


\begin{tabular}{|c|l|}
\hline Fini $_{e, i}$ & $\begin{array}{l}\text { Initial fishing mortality coefficient (here, by species } \\
\text { and age) }\end{array}$ \\
\hline$C_{e, f, m, i}$ & $\begin{array}{l}\text { Splitting variable at a given level (here, catch by } \\
\text { species, métier and age) }\end{array}$ \\
\hline Ctot $_{e, i}$ & $\begin{array}{l}\text { Total splitting variable (must be defined at the } \\
\text { crossing level of the two previous variables) }\end{array}$ \\
\hline
\end{tabular}

Table 2 - Input parameters for the sub-module « fishing mortality allocation »

\section{- Calculated variable}

950

\begin{tabular}{|c|c|c|c|}
\hline Notation & Type & \multicolumn{1}{|c|}{ Description } & Equation \\
\hline Fini $_{e, f, m, i}$ & output & $\begin{array}{l}\text { Instantaneous fishing mortality } \\
\text { coefficient allocated by f,m }\end{array}$ & Fini $_{e, f, m, i}=\frac{\text { Fini }_{e, i} \times C_{e, f, m, i}}{\text { Ctot }_{e, i}}$ \\
\hline
\end{tabular}

Table 3 - Output parameters for the sub-module « fishing mortality allocation »

952

\subsection{Sub-module catchability estimation}

954

The catchability coefficient is estimated from the initial fishing mortality and corresponding fishing

- Initial parameters

\begin{tabular}{|c|c|}
\hline Notation & Description \\
\hline Eini $_{f, m}$ & Initial effort by fleet and métier \\
\hline
\end{tabular}

Table 4 - Input parameters for the sub-module « catchability estimation »

• Calculated variables
\begin{tabular}{|c|l|l|c|}
\hline Notation & \multicolumn{1}{|c|}{ Type } & \multicolumn{1}{|c|}{ Description } & Equation \\
\hline$q_{e, f, m, i}$ & Sortie & $\begin{array}{l}\text { Catchability (by species, fleet, métier and } \\
\text { age) }\end{array}$ & $q_{e, f, m, i}=\frac{\text { Fini }_{e, f, m, i}}{\text { Eini }_{f, m}}$ \\
\hline
\end{tabular}




\subsection{Module Fishing mortality}

This module uses the two methods described above. It produces fishing mortality partitioned into

fleets and métier. The other category contains residual fishing mortality not accounted for by the fleet or métier considered in the analysis.

\begin{tabular}{|c|l|}
\hline Notation & \multicolumn{1}{|c|}{ Description } \\
\hline$d_{e, f, m, l}$ doth $_{e, i}$ & $\begin{array}{l}\text { Percentage of total catch discarded in number (by } \\
\text { species, fleet, métier and age) resp. by other fleets, } \\
\text { species and age }\end{array}$ \\
\hline$s r_{e}$ & Survival rate of discards (by species) \\
\hline$E_{f, m}$ & Effort by fleet and metier \\
\hline
\end{tabular}

- $\quad$ Calculated variables

\begin{tabular}{|c|c|c|c|}
\hline Notation & Type & Description & Equation \\
\hline$K_{e, f, m, i}$ & Internal & $\begin{array}{l}\text { Correcting factor of fishing mortality } \\
\text { linked to discards survival }\end{array}$ & $K_{e, f, m, i}=1-s r_{e} \cdot d_{e, f, m, i}$ \\
\hline$F r_{e, f, m, i, t}$ & Output & $\begin{array}{l}\text { Fishing mortality (by species, fleet, } \\
\text { métier and age, at time } t) . \text { Input for } \\
\text { module Catch et Population dynamics }\end{array}$ & $F r_{e, f, m, i, t}=q_{e, f, m, i} \cdot E_{f, m, t} . K_{e, f, m, i}$ \\
\hline Froth $h_{e, i}$ & Output & $\begin{array}{l}\text { Initial mortality « other fleets, other } \\
\text { métier » by species and age. Input for } \\
\text { module Catch et Population dynamics }\end{array}$ & Froth ${ }_{e, i}=F_{e, i}-\sum_{f, m} F r_{e, f, m, i, 0}$ \\
\hline
\end{tabular}

\begin{tabular}{|c|l|}
\hline Notation & \multicolumn{1}{|c|}{ Description } \\
\hline$N_{e, i, t=0}$ & $\begin{array}{l}\text { Total number at age by species at } \mathrm{t}=0 \text { and total } \\
\text { number of recruits by species }\end{array}$ \\
\hline
\end{tabular}


976

977

978

979

980

981

982

983

984

986

987

\begin{tabular}{|c|l|}
\hline et $N_{e, i=0, t}$ & \\
\hline$M_{e, i}$ & Natural mortality rate by age and species \\
\hline$w_{e, i}$ & Individual Weight at age by species in the stock \\
\hline
\end{tabular}

Table 8- Initial parameters for the module « Population dynamics»

\section{8}

\section{- Calculated variables}

\begin{tabular}{|c|l|l|c|}
\hline Notation & \multicolumn{1}{|c|}{ Type } & \multicolumn{1}{|c|}{ Description } & Equation \\
\hline$Z_{e, i, t}$ & Output & $\begin{array}{l}\text { Total mortality rate (by species } \\
\text { and age at time t). Input to } \\
\text { module Catch. }\end{array}$ & $Z_{e, i, t}=M_{e, i}+\sum_{f, m} F r_{e, f, m, i, t}+F o t h_{e, i}$ \\
\hline$N_{e, i, t}$ & Output & $\begin{array}{l}\text { Number at age by species at } \\
\text { time t. }\end{array}$ & $N_{e, i+1, t+1}=N_{e, i, t} \cdot e^{-Z_{e, i, t}+N_{e, i+1, t} \cdot e^{-Z_{e, i+1, t}}}$ \\
\hline$B_{e, t}$ & Output & $\begin{array}{l}\text { Total biomass by species at } \\
\text { time t. }\end{array}$ & \multicolumn{1}{c}{\begin{tabular}{c}
$N_{e, t}=\sum_{i} N_{e, i, t} \cdot w_{e, i}$ \\
\hline
\end{tabular}} \\
\hline
\end{tabular}

Table 9 - Calculated parameters for the module «Population dynamics »

\section{Module Catch, discards and landings (based on Baranov equation)}

- Initial parameters

\begin{tabular}{|c|l|}
\hline Notation & \multicolumn{1}{|c|}{ Description } \\
\hline$w D_{e, i}$ & $\begin{array}{l}\text { Average weight of discarded individual by species and } \\
\text { age }\end{array}$ \\
\hline$w C_{e, i}$ & $\begin{array}{l}\text { Average weight of individual in the catch by species } \\
\text { and age }\end{array}$ \\
\hline
\end{tabular}

Table 10 - Initial parameters in the module «Catch, discards and landings »

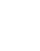

(1)

- Calculated variables
\begin{tabular}{|l|c|c|c|}
\hline Notation & Type & Description & Equation \\
\hline
\end{tabular}




\begin{tabular}{|c|c|c|c|}
\hline$C_{e, f, m, i, t}$ & Output & $\begin{array}{l}\text { Catch in numbers (by } \\
\text { species, fleet, métier and } \\
\text { age over period } \mathrm{t} \text { ). }\end{array}$ & $C_{e, f, m, i, t}=\frac{F r_{e, f, m, i, t}}{Z_{e, i, t}} \times N_{e, i, t} \times\left(1-e^{-Z_{e, i, t}}\right)$ \\
\hline$C_{e, i, t}$ & Output & $\begin{array}{l}\text { Catch in numbers (by } \\
\text { species and age over } \\
\text { period t) }\end{array}$ & $C_{e, i, t}=\frac{\sum_{f, m} F r_{e, f, m, i, t}+\text { Foth }_{e, i}}{Z_{e, i, t}} \times N_{e, i, t} \times\left(1-e^{-2}\right.$ \\
\hline$Y_{e, f, m, i, t}$ & Output & $\begin{array}{l}\text { Catch in weight (by } \\
\text { species, fleet, métier and } \\
\text { age over period } \mathrm{t} \text { ). }\end{array}$ & $Y_{e, f, m, i, t}=w C_{e, i} \times C_{e, f, m, i, t}$ \\
\hline$Y_{e, i, t}$ & Output & $\begin{array}{l}\text { Catch in weight (by } \\
\text { species and age over } \\
\text { period } \mathrm{t} \text { ). }\end{array}$ & $Y_{e, i, t}=w C_{e, i} \times C_{e, i, t}$ \\
\hline$D_{e, f, m, i, t}$ & Output & $\begin{array}{l}\text { Discards in weight (by } \\
\text { species, fleet, métier and } \\
\text { age over period t). }\end{array}$ & $\begin{array}{c}D_{e, f, m, i, t}=d_{e, f, m, i} \times w D_{e, i} \times C_{e, f, m, i, t} \text { if } w D_{e, i} \\
\text { available, } \\
D_{e, f, m, i, t}=d_{e, f, m, i} \times Y_{e, f, m, i, t} \text { otherwise. }\end{array}$ \\
\hline$L_{e, f, m, i, t}$ & Output & $\begin{array}{l}\text { Landings in weight (by } \\
\text { species, fleet, métier and } \\
\text { age over period t). Input } \\
\text { in module Market. }\end{array}$ & $L_{e, f, m, i, t}=Y_{e, f, m, i, t}-D_{e, f, m, i, t}$ \\
\hline
\end{tabular}

988

Table 11 - Calculated parameters for the module «Catch, discards and landings »

\section{Market/price Module}

The market/price module has two functions:

The first function is to aggregate productions by age and species into productions by grade and species according to an age-grade key matrix.

The second function is to calculate the price by grade and species that can either be an input parameter or result from a price model function (of the production by grade, the importations, exportations etc.). In the second case parameters of the price model are included in the input file. The following table gives an example of price function that could be implemented in the model.

- Initial parameters

\begin{tabular}{|l|l|}
\hline \multicolumn{1}{|c|}{ Notation } & Description \\
\hline$\alpha_{e, c}$ & Constant of the price model specific to each commercial grade $c$ \\
\hline
\end{tabular}




\begin{tabular}{|l|l|}
\hline$\beta_{e, c}$ & Price elasticity of grade $c$ \\
\hline$\gamma_{e, c}$ & Cross elasticity with other grades for grade $c$ \\
\hline icat $_{e, i, c}$ & Transformation Matrix for age/grade by species: $\mathrm{P}_{\mathrm{e}}(\mathrm{c} / \mathrm{i})$ \\
\hline $\mathrm{mat}_{f, m 1, m 2}$ & Correspondance métier-species-grade with métier \\
\hline$P_{e, f, m,(c,) t}$ & $\begin{array}{l}\text { Mean price per species, fleet, métier, category at t. Used as an input } \\
\text { for the economic module if the market module is not activated }\end{array}$ \\
\hline
\end{tabular}

1001

1002

1003

1004

1005

1006

1007

1008

1009

1010

1011

1012

1013

1014

1015

1016

1017

Table 12 -Initial Parameters for the Price/market module

\section{- Calculated variables}

\begin{tabular}{|c|c|c|c|}
\hline Notation & Type & \multicolumn{1}{|c|}{ Description } & Equation \\
\hline$L_{e, f, m, c, t}$ & Internal & $\begin{array}{l}\text { Catches in Weight (by species, } \\
\text { fleet, metier, grade at t) }\end{array}$ & $L_{e, f, m 1, c, t}=\sum_{i}\left(L_{e, f, m, i, t} \times i_{c a t} t_{e, i, c}\right)$ \\
\hline$P_{e, c, t}$ & Output & $\begin{array}{l}\text { Mean price (by species, grade for t) } \\
\text { input of the economic module }\end{array}$ & $\begin{array}{l}\ln P_{e, c, t}=\alpha_{e, c}+\beta_{e, c} \times \ln \left(\sum_{f, m} L_{e, f, m, c, t}\right) \\
+\gamma_{e, c} \times \ln \left(\sum_{f, m, c a t \neq c} L_{e, f, m, c a t, t}\right)\end{array}$ \\
\hline
\end{tabular}

Table 13 - Variables calculated for the Price/market module

\section{Economic module}

The economic module produces indicators of performances for consumers, state and producers including indictors for the whole fishery, by fleet, by mean vessel per fleet.

The economic module relies on input data based on data collected within the DCF $^{12}$ as well as data from the SACROIS data source which is an algorithm crossing multiple existing data sources (auction halls, logbooks, dealer reports) to provide the best possible estimation of effort and production by vessel at the trip level (source: IFREMER/Fisheries Information System/DPMA). Appendix VI of the European Decision No 199/2008 gives the following list of economic variables to be collected by fleet and member state.

\footnotetext{
${ }^{12}$ COMMISSION DECISION 2008/949/EC of 6 November 2008, adopting a multiannual Community programme pursuant to Council Regulation (EC) No 199/2008 establishing a Community framework for the collection, management and use of data in the fisheries sector and support for scientific advice regarding the common fisheries policy.
} 


\begin{tabular}{|c|c|}
\hline Variable Group & Variable \\
\hline Income & $\begin{array}{l}\text { Gross value of landings } \\
\text { Income from leasing out quota or other fishing rights } \\
\text { Direct subsidies } \\
\text { Other income }\end{array}$ \\
\hline Personnel costs & $\begin{array}{l}\text { Wages and salaries of crew } \\
\text { Imputed value of unpaid labour }\end{array}$ \\
\hline Energy costs & Energy costs \\
\hline Repair and maintenance costs & Repair and maintenance costs \\
\hline Other operational costs & $\begin{array}{l}\text { Variable costs } \\
\text { Non-variable costs } \\
\text { Lease/rental payments for quota or other fishing rights }\end{array}$ \\
\hline Capital costs & Annual depreciation \\
\hline Capital value & $\begin{array}{l}\text { Value of physical capital: depreciated replacement value } \\
\text { Value of physical capital: depreciated historical value } \\
\text { Value of quota and other fishing rights }\end{array}$ \\
\hline Investments & Investments in physical capital \\
\hline Financial position & Debt/asset ratio \\
\hline Employment & $\begin{array}{l}\text { Engaged crew } \\
\text { FTE National } \\
\text { FTE harmonised }\end{array}$ \\
\hline Fleet & $\begin{array}{l}\text { Number } \\
\text { Mean LOA } \\
\text { Mean vessel's tonnage } \\
\text { Mean vessel's power } \\
\text { Mean age }\end{array}$ \\
\hline Effort & Days at sea \\
\hline
\end{tabular}




\section{Energy consumption}

Number of fishing enterprises/units Number of fishing enterprises/units

Value of landings per species

Production value per species

Average price per species

Table 14 - Economic and transversal variables collected within the appendix VI (EC) No 199/2008

The model works with a subset of the economic and transversal indicators (landings data in quantity and value by species by fleet and metier) collected within the DCF and with other indicators from external data sources available. Inputs parameters are listed below.

The economic module calculates outputs indicators using economic indictors listed above and outputs from the biological and the market modules.

- Input parameters

\begin{tabular}{|c|c|}
\hline Notation & Description \\
\hline \multicolumn{2}{|l|}{ TRANSVERSAL DATA } \\
\hline$n b v_{f}$ & $\mathrm{Nb}$ vessels \\
\hline$n d s_{f}$ & Days/ Days at sea \\
\hline$c n b_{f}$ & Employment \\
\hline$G V L_{f}$ & $\begin{array}{l}\text { Income_landing/ Gross value of } \\
\text { landings }\end{array}$ \\
\hline$L_{e, f}$ & $\begin{array}{l}\text { Landings by species and fleet, output } \\
\text { from Catches module }\end{array}$ \\
\hline$G V L_{e, f}$ & $\begin{array}{l}\text { Income_landing/ Gross value of } \\
\text { landings by species }\end{array}$ \\
\hline \multicolumn{2}{|c|}{ If data by métier are available } \\
\hline$L_{e, f, m}$ & $\begin{array}{l}\text { Landings by modelled species and fleet } \\
\text { /metier, output from Catches module }\end{array}$ \\
\hline$G V L_{e, f, m}$ & $\begin{array}{l}\text { Income_landing/ Gross value of } \\
\text { landings by metier by modelled }\end{array}$ \\
\hline$G V L_{f, m}$ & $\begin{array}{l}\text { Income_landing/ Gross value of } \\
\text { landings metier }\end{array}$ \\
\hline
\end{tabular}




\begin{tabular}{|c|c|}
\hline$n d s_{f, m}$ & Days/ Days at sea by fleet and métier \\
\hline \multicolumn{2}{|l|}{ DCF ECONOMIC DATA } \\
\hline$F c_{f}$ & Fuelcost/ Energy costs \\
\hline $\mathrm{Fvol}_{f}$ & Fuelcons/ Energy consumption \\
\hline$o v c_{f}$ & Varcost/ other variable costs \\
\hline rep $_{f}$ & Repcost/ Repair and maintenance costs \\
\hline Fixc $_{f}$ & Fixedcost/other non variable costs \\
\hline$c c W_{f}$ & Crew costs wages \\
\hline $\operatorname{dep}_{f}$ & Depreciation costs \\
\hline$K_{f}$ & $\begin{array}{l}\text { Capital/ insurance value of vessel as } \\
\text { proxy }\end{array}$ \\
\hline $\ln v_{f}$ & Investment costs by fleet \\
\hline persc $_{f}$ & Crew costs of the fleet \\
\hline \multicolumn{2}{|l|}{ If data by métier are available } \\
\hline$F c_{f m}$ & Fuelcost/ Energy costs \\
\hline Fvol $_{f m}$ & Fuelcons/ Energy consumption \\
\hline$o v c_{f m}$ & Varcost/ other variable costs \\
\hline \multicolumn{2}{|l|}{$\begin{array}{l}\text { ECONOMIC DATA FROM } \\
\text { EXTERNAL SOURCES }\end{array}$} \\
\hline$I c_{f}$ & Landing costs (\% GR) \\
\hline$n b h_{f}$ & $\begin{array}{l}\mathrm{Nb} \text { of hours at sea by year } \\
\text { Harmonized reference } 2000 \text { h }(250 \\
\text { days at sea* } 8 \text { hours/day) }\end{array}$ \\
\hline $\operatorname{cshr}_{f}$ & $\begin{array}{l}\text { Crew share (\% of the Return to be } \\
\text { Shared) }\end{array}$ \\
\hline$m w h$ & Net Minimum national wage \\
\hline mwhg & Gross Minimum national wage \\
\hline
\end{tabular}




\begin{tabular}{|l|l|}
\hline$i c_{f}$ & $\begin{array}{l}\text { Interest costs/opportunity costs of } \\
\text { capital }\end{array}$ \\
\hline$e e c_{f}$ & Crew costs contribution \\
\hline
\end{tabular}

1028

1029

1030

1031

1032

1033

1034

1035

1036

Table 15 -Inputs parameters of the economic module

- Calculated variables

Indicators of type ini are intermediate indicators calculated at the beginning from the input data and used in the model after to calculate the output indicators. Indicators denoted 1 in the last column can be calculated only with DCF data, indicators denoted 2 requires external data sources that are not available in all the cases.

\begin{tabular}{|c|c|c|c|}
\hline Notation & Type & Description & Equation \\
\hline \multicolumn{4}{|l|}{ Indicators ini } \\
\hline GVLoths $_{f}$ & Ini & GR other species by fleet & $G V \operatorname{Loths}_{f}=G V L_{f}-\sum_{\rho} G V L_{e, f}$ \\
\hline GVLothsue $_{f}$ & Ini & $\begin{array}{l}\text { GR other species by fleet } \\
\text { and unit of effort in case } \\
\text { uef=uefm }\end{array}$ & GVLothsue $_{f}=\frac{G \text { VLoths }}{u}$ \\
\hline GVLothsue $_{f}$ & Ini & $\begin{array}{l}\text { GR other species by fleet } \\
\text { and unit of effort in case } \\
\text { Cas uef<> uefm }\end{array}$ & GVLothsue $_{f}=\frac{\text { GVLoths }_{f}}{\left(u e_{f}-\sum_{m} u e_{f, m}\right)}$ \\
\hline \multicolumn{4}{|c|}{ If data by métier are available } \\
\hline GVLoths $s_{f, m}$ & Ini & $\begin{array}{l}\text { GR other species by fleet } \\
\text { métier }\end{array}$ & $G V \operatorname{Loth}_{f, m}=G V L_{f, m}-\sum_{e} G V L_{e, f, m}$ \\
\hline GVLothsue $_{f, m}$ & Ini & $\begin{array}{l}\text { GR other species by fleet } \\
\text { and unit of effort métier }\end{array}$ & GVLothsue $_{f, m}=\frac{\text { GVLoths }_{f, m}}{u e_{f, m}}$ \\
\hline GVLothmet $_{f}$ & Ini & GR other métiers by fleet & $G V$ Lothmet $_{f}=G V L_{f}-\sum_{m} G V L_{f, m}$ \\
\hline GVLothmetue $_{f}$ & Ini & $\begin{array}{l}\text { GR other métiers by fleet } \\
\text { and unit of effort }\end{array}$ & GVLothmetue $_{f}=\frac{\text { GVLothmet }_{f}}{u e_{f}-\sum_{m} u e_{f, m}}$ \\
\hline$p f_{f}$ & Ini & Fuel price euros/L & $p f_{f}=\frac{F c_{f i n i}}{F v o l_{f i n i}}$ \\
\hline
\end{tabular}




\begin{tabular}{|c|c|c|c|}
\hline Fvolue $_{f}$ & Ini & $\begin{array}{l}\text { Fuel consumption by unit } \\
\text { of effort ( } n b \text { of days at } \\
\text { sea) }\end{array}$ & Fvolue $_{f}=\frac{F_{\text {vol }}}{n d s_{f i n i}}$ \\
\hline \multicolumn{4}{|c|}{ Output indicators } \\
\hline$G V L_{f}$ & Output & $\begin{array}{l}\text { Total gross revenue by } \\
\text { fleet }\end{array}$ & $\begin{array}{l}G V L_{f}=\sum_{e, c}\left(P_{e, c} \times L_{e, f, c}\right) \\
\text { a. } \\
+G V L o t h s u e_{f} * u e_{f} \\
\text { if it is assumed that the fleet has only one } \\
\text { métier } \\
G V L_{f}=\sum_{e, c}\left(P_{e, c} \times L_{e, f, c}\right) \\
\text { b. }+G V L o t h s u e_{f} *\left(u e_{f}-\sum_{m} u e_{f, m}\right) \\
\text { if it is assumed that the GR other species comes } \\
\text { from other metier and that there is a } \\
\text { reallocation of effort when effort of the } \\
\text { modelled metier decreases (requires an } \\
\text { estimation of the effort by metier) } \\
G V L_{f}=\sum_{e, c}\left(P_{e, c} \times L_{e, f, c}\right) \\
\text { c. } \\
+G V L o t h s_{f} \\
\text { if it is assumed that the GR other species comes } \\
\text { from other metier and that there is no } \\
\text { reallocation of effort (requires an estimation of } \\
\text { the effort by metier) }\end{array}$ \\
\hline \multicolumn{4}{|c|}{ If data by métier are available } \\
\hline$G V L_{f, m}$ & Output & $\begin{array}{l}\text { Total gross revenue by } \\
\text { fleet métier }\end{array}$ & $\begin{array}{l}G V L_{f, m}=\sum_{e, c}\left(P_{e, c} \times L_{e, c, f, m}\right) \\
+G \text { VLothsue } \text { f }_{f, m} * u e_{f, m}\end{array}$ \\
\hline$G V L_{f}$ & Output & $\begin{array}{l}\text { Total gross revenue by } \\
\text { fleet }\end{array}$ & $\begin{array}{l}G V L_{f}=\sum_{m} G V L_{f, m} \\
\text { a. }+G V \text { Lothmetue }_{f} *\left(u e_{f}-\sum_{m} u e_{f, m}\right) \\
\text { if it is assumed that there is a reallocation of } \\
\text { effort when effort of the modelled metier } \\
\text { decreases }\end{array}$ \\
\hline
\end{tabular}




\begin{tabular}{|c|c|c|c|}
\hline & & & $\begin{array}{l}\quad G V L_{f}=\sum_{e, c}\left(P_{e, c} \times L_{e, f, c}\right) \\
\text { b. } \\
+G V \text { Lothmet }_{f} \\
\text { if it is assumed that there is no reallocation of } \\
\text { effort }\end{array}$ \\
\hline \multicolumn{4}{|c|}{ Output indicators calculated regardless of métier data availability } \\
\hline$G L_{a} v_{f}$ & Output & $\begin{array}{l}\text { Mean gross revenue by } \\
\text { vessel by fleet }\end{array}$ & $G V L a v_{f}=\frac{G V L_{f}}{n b v_{f}}$ \\
\hline NGVLav $_{f}$ & Output & $\begin{array}{l}\text { Mean ret revenue by } \\
\text { vessel by fleet }\end{array}$ & $N G V L a v_{f}=G V L a v_{f}\left(1-l c_{f}\right)$ \\
\hline$r t b s_{f}$ & Output & $\begin{array}{l}\text { Return to be shared by } \\
\text { vessel by fleet }\end{array}$ & $\begin{array}{l}r t b s_{f}=G V L a v_{f}-p f_{f} . \text { Fvolue }_{f} . n d s_{f} \\
-o v c_{f}\end{array}$ \\
\hline$g v a_{f}$ & Output & $\begin{array}{l}\text { Gross Value Added by } \\
\text { vessel by fleet }\end{array}$ & $\begin{array}{l}g v a_{f}=G V L a v_{f}-p f_{f} . \text { Fvolue }_{f} . n d s_{f} \\
-o v c_{f}-\text { rep }_{f}-\text { Fixc }_{f}\end{array}$ \\
\hline$g c f_{f}$ & Output & $\begin{array}{l}\text { Gross Cash Flow or gross } \\
\text { profit by vessel by fleet }\end{array}$ & $\begin{array}{l}g c f_{f}=G V L a v_{f}-p f_{f} . \text { Fvolue }_{f} . n d s_{f} \\
-o v c_{f}-r e p_{f}-\text { Fixc }_{f}-c c w_{f} \\
=g v a_{f}-c c w_{f}\end{array}$ \\
\hline$n c f_{f}$ & Output & $\begin{array}{l}\text { Net Cash Flow by vessel } \\
\text { by fleet }\end{array}$ & $n c f_{f}=g c f_{f}-d e p_{f}$ \\
\hline$n p_{f}$ & Output & $\begin{array}{l}\text { Net Profit by vessel by } \\
\text { fleet or Owner surplus }\end{array}$ & $n p_{f}=n g c f_{f}-i c_{f}$ \\
\hline ROFTA $_{f}$ & Output & $\begin{array}{l}\text { Rate of return on Fixed } \\
\text { Tangible asset }\end{array}$ & $\operatorname{ROFTA}_{f}=\frac{n c f_{f}}{K_{f}}$ \\
\hline$R^{\prime} I_{f}$ & output & Return on Investment & $R O I_{f}=\frac{g c f_{f}-I n v_{f}}{i n v_{f}}$ \\
\hline \multicolumn{4}{|c|}{ If crew share unavailable } \\
\hline$C c w_{-} r_{f}$ & Ini & $\begin{array}{l}\text { Crew costs share as a \% } \\
\text { of the RTBS }\end{array}$ & $\begin{array}{l}C c w_{-} r_{f}=\frac{C c w_{f} \operatorname{Ini}}{r t b s_{f} \text { Ini }} \\
=\frac{C c w_{f} \text { Ini }}{\left(G V L a v_{f}-p f_{f} \cdot \text { Fvolue }_{f} . n d s-o v c_{f}\right) \operatorname{Ini}}\end{array}$ \\
\hline
\end{tabular}




\begin{tabular}{|c|c|c|c|}
\hline$C_{c} w_{f}$ & Output & Crew costs & $\begin{array}{l}C c w_{f}=C c w_{-} r_{f} * r t b s_{f} \\
=C c w_{-} r_{f} \\
*\left(G V L a v_{f}-p f_{f} . \text { Fvolue }_{f} . n d s-o v c_{f}\right)\end{array}$ \\
\hline $\operatorname{CcwCr}_{f}$ & Output & $\begin{array}{l}\text { Crew costs by crew } \\
\text { member }\end{array}$ & $C c w_{f_{\mathrm{f}}}=\frac{C c w_{f}}{c n b_{f}}$ \\
\hline \multicolumn{4}{|c|}{ If crew share available } \\
\hline opersc $_{f}$ & $\operatorname{Ini}$ & $\begin{array}{l}\text { Other crew costs = } \\
\text { vacation, employer } \\
\text { contribution, premium }\end{array}$ & $\begin{array}{l}\text { opersc }_{f}=C c w_{f} \text { Ini }_{-} \text {cshr }_{f} * r t b s_{f} \text { Ini } \\
=C c w_{f} \text { Ini }_{-}-\operatorname{csh} r_{f} \\
*\left(G V L a v_{f}-p f_{f} . \text { Fvolue }_{f} . n d s-o v c_{f}\right) \text { Ini }\end{array}$ \\
\hline $\mathrm{CcW}_{f}$ & Output & Crew costs & $C c w_{f}=c s h r_{f} * r t b s_{f}+$ opersc $_{f}$ \\
\hline $\operatorname{CcwCr}_{f}$ & Output & $\begin{array}{l}\text { Crew costs by crew } \\
\text { member }\end{array}$ & $C c w_{f_{\mathrm{f}}}=\frac{C c w_{f}}{c n b_{f}}$ \\
\hline$s s h r_{f}$ & Output & $\begin{array}{l}\text { Owner share by vessel } \\
\text { by fleet }\end{array}$ & $s s h r_{f}=r t b s_{f}\left(1-c s h r_{f}\right)$ \\
\hline $\operatorname{cshr} T_{f}$ & Output & $\begin{array}{l}\text { Crew share by vessel by } \\
\text { fleet }\end{array}$ & $c \operatorname{sh} r T_{f}=c \operatorname{sh} r_{f} \times r t b s_{f}$ \\
\hline wageg $_{f}$ & Output & $\begin{array}{l}\text { Gross wage by crew } \\
\text { member including crew } \\
\text { contributions }\end{array}$ & $\operatorname{wageg}_{f}=\frac{c s h r T_{f}}{c n b_{f}}$ \\
\hline \multicolumn{4}{|c|}{ Surplus calculation } \\
\hline$c s g_{f}$ & Output & $\begin{array}{l}\text { Gross Labour surplus by } \\
\text { fleet }\end{array}$ & $\operatorname{csg} g_{f}=c s h r_{f}-o c \lg g_{f}$ \\
\hline$o c l g$ & Output & $\begin{array}{l}\text { Opportunity costs of } \\
\text { Labour by fleet }\end{array}$ & $o c l_{f}=m w h g \times c n b_{f} \times n b h_{f}$ \\
\hline$p s g_{f}$ & Sortie & $\begin{array}{l}\text { Total producer surplus by } \\
\text { fleet (gross value) }\end{array}$ & $p s g_{f}=n b v_{f} \times\left(c s g_{f}+g p_{f}\right)$ \\
\hline$n c s h r_{f}$ & Output & Net crew share by fleet & $n c s h r_{f}=c \operatorname{csh} r T_{f}-e e c_{f}$ \\
\hline wagen $_{f}$ & Output & $\begin{array}{l}\text { Net wage by crew } \\
\text { member }\end{array}$ & wagen $_{f}=\frac{n c s h r_{f}}{c n b_{f}}$ \\
\hline
\end{tabular}




\begin{tabular}{|c|l|l|l|l|}
\hline$c s_{f}$ & Sortie & Labour surplus by fleet & $c s_{f}=n c s h r_{f}-o c l_{f}$ & \\
\hline ocl & Sortie & $\begin{array}{l}\text { Net Opportunity costs of } \\
\text { Labour by fleet }\end{array}$ & $o c l_{f}=n m w h \times c n b_{f} \times n b h_{f}$ & \\
\hline$p s_{f}$ & Sortie & $\begin{array}{l}\text { Total producer surplus by } \\
\text { fleet }\end{array}$ & $p s_{f}=n b v_{f} \times\left(c s_{f}+g p_{f}\right)$ & \\
\hline If landings costs available & $\begin{array}{l}\text { State surplus associated } \\
\text { to one fleet }\end{array}$ & $s t s_{f}=l c_{f} \times G V L a v_{f} \times n b v_{f}$ & \\
\hline \multicolumn{5}{|l}{ Sts } \\
\hline
\end{tabular}

1037

1038

1039

1040

1041

1042

1043

1044

1045

1046

1047

1048

1049

1050

1051

1052

1053

1054

1055

1056

1057

1058

1059

1060

Table 16 - Output variables of the economic module

Economic indicators can be calculated:

- by mean vessel by fleet

- by fleet

- for the whole fishery

to analyze impacts of scenarios on the individual performances of vessels, the performances of the fleets or the whole performances of the fishery.

Other output indicators derived from the outputs described (e.g. ratio outputs) are available or can be created for the analyses.

Cost-benefit analyses of scenarios are evaluated through the total surplus variation (producer, consumer, and state surplus variation) of the scenario compared to status quo in term of net present value. Sensitivity to discount rate can be analysed.

Note that several options have been added to calculate the crew costs according to the remuneration system based on share system or fixed wages. They are not detailed in this document. See Guillen et al., $2015^{13}$ and $2017^{14}$ for more development on this aspect.

\section{Scenarios and management module}

Control variables of the model are:

- The exploitation pattern through a selectivity factor

- The fishing effort through variations of the activity by vessel (number of days at sea) or of the number of vessels by fleet

- The TAC through the variation of activity and number of vessels such that the TAC is reached according to the stock abundance

${ }^{13}$ Guillen Jordi, Macher Claire, Merzereaud Mathieu, Boncoeur Jean, Guyader Olivier (2015). Effects of the Share Remuneration System on Fisheries Management Targets and Rent Distribution. Marine Resource Economics, 30(2), 123-138. Publisher's official version : http://doi.org/10.1086/679970, Open Access version : http://archimer.ifremer.fr/doc/00260/37086/

${ }^{14}$ Guillen Jordi, Boncoeur Jean, Carvalho Natacha, Frangoudes Katia, Guyader Olivier, Macher Claire, Maynou Francesc (2017). Remuneration systems used in the fishing sector and their consequences on crew wages and labor rent creation. Maritime Studies, 16(3), 1-36. Publisher's official version : http://doi.org/10.1186/s40152017-0056-6, Open Access version : http://archimer.ifremer.fr/doc/00375/48602/ 
- A Fishing mortality objective reached through time step decrease of number of days at sea or of number of vessels

Besides, all the input parameters can be modified through various scenarios at any time of the simulation. It is thus possible to test for example the impacts of evolution of :

- fuel price

- number of vessels by fleet

- ex-vessels prices

$-\quad \ldots$

\section{Stochasticity module}

For each variable of the model, this module can specify a probability law to take into account of uncertainties in the model.

\section{Behaviour module}

This module is designed to include short and long term behaviours of investment/disinvestment, discarding, effort allocation, compliance, etc.

Long term behaviours concerns fleet dynamics of investment/disinvestment according to profit.

Following options can be modelled and compared in the model:

- Constant number of vessels

- Capacity adjustment of number of vessels in the fishery according to different weighting

- fleet dynamics of entry/exit according to profit (investment if positive profit, exit from fishery according to capital malleability Garcia et al., 2012) or decommissioning schemes (Guyader et al 2004) as described in Bellanger et al., 2018.

Short term behaviours concerns effort adjustment to quota constraints or reallocation by metier.

Three alternative behaviours can be considered under multi-species and quotas constraints:

- lowest quota behaviors assuming that fleets stop fishing when the first quota is reached (assumption of full observation of the landing obligation) (reallocation of the effort of the fleet among métiers according to habits and/or profitability can be an additional option in this configuration)

- highest quota behavior assuming that fleets keep fishing until the last quota is consumed and discards over-consumption of quotas

- maximum profit behavior under Tac constraints

Fishing effort is the main driver used by behaviour model to impact on fishing activity within :

- different levers / components of effort :

- effort per vessel : $\mathrm{nb}$ days at sea, fishing time (mean trip duration, $\mathrm{nb}$ of trips), ,... 
- different targets (and ways to reach them) :

- TAC or/then F (uni or multidimensional)

- Non transferable individual quotas (multi)

- MSY ranges / reconciliation (iterated uni or multi)

- Profit maximization under ITQ system (multi)

- $\quad$... and other applications

- different kind of impacts on effort:

- Uniform adjustment of effort per fleet/métier targeting species

- Weighted adjustment of effort per fleet/métier (according to contribution to species landings for example or according to marginal profits and habits(Marchal et al 2009,2013))

- Multi-dimensional resolution (profit maximisation, profit-tradition, ...) :

\section{Parameterization and $\mathrm{R}$ package}

A special effort has been made to ensure that the IAM model has a relatively simple parameterization system to approach, despite the diversity of inputs that a multi-specific, multi-fleet and multi-metier bioeconomic model induces. For this, it was agreed that the input data of the model would be contained in an Excel file of extension ".xls", having a specific structure, and readable by an import procedure integrated into the tool.

The input file consists of the following sheets: a "Stock" sheet per model species, a "fleet" sheet per modeled fleet, a "market" sheet containing the price or parameters of the market module by species, sheets containing the conversion tables (matrix age-category, métier bio-métier éco), a "Scenarii" sheet and a leaflet "Stochasticity". The options of use of the model are specified separately at the launch of the simulations.

Fleets and market sheets are created from data processing methods connected to exiting databases for french fleets. They can be integrated to the $\mathrm{R}$ input object directly from csv files.

The bio-economic IAM model has been developed with the aim of being usable in an R environment. The tool is thus accessible via an R package integrating a set of methods covering all stages of the modeling, from the parameterization phase to the output of the model. Several methods including methods for input import (IAM input), simulation setting (IAM.args) or output formatting into data.frame for graphical representation (lam.format) have been developed as part of the Package. 
Supplementary material 2 : Example of synthetic figures illustrating trade-offs between multi-criteria dimensions for scenarios tested in the three case studies

Figure a. Synthetic representation of multi-criteria impacts of scenarios tested in the Bay of SaintBrieuc scallop fishery

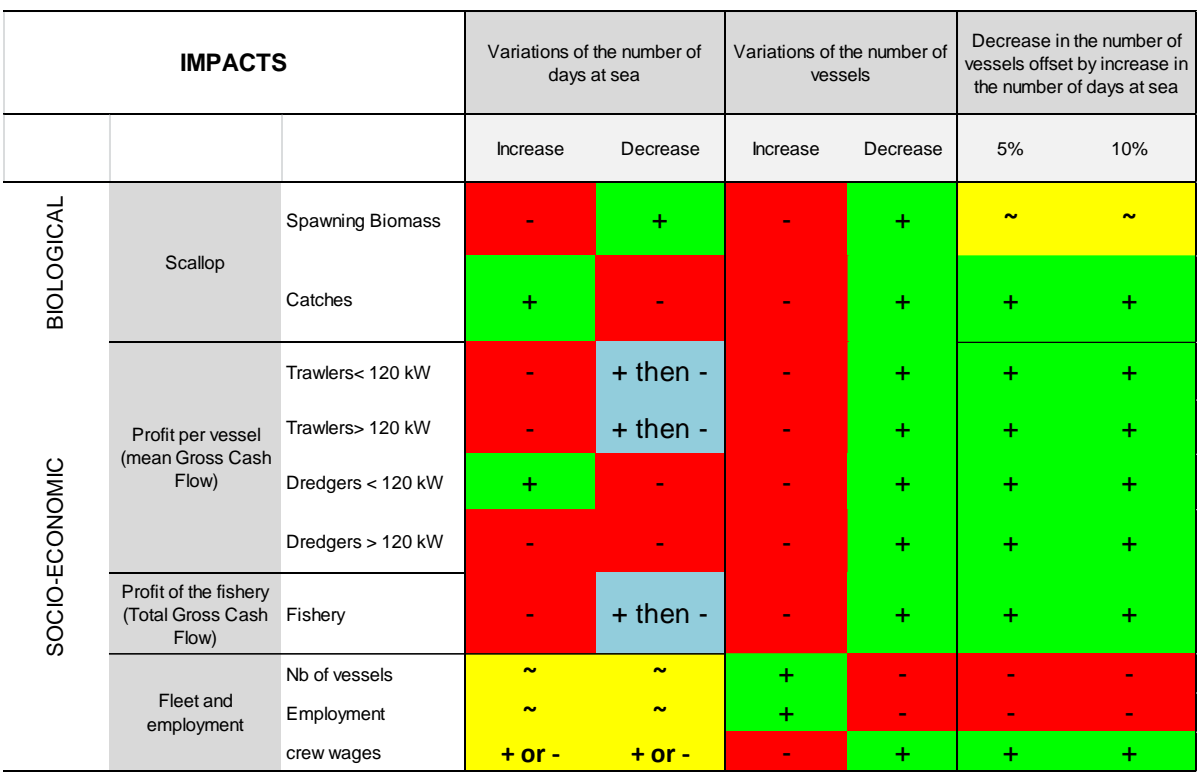

\begin{tabular}{|c|c|}
\hline - & negative impacts \\
\hline$\sim$ & undifferentiated or no impact \\
\hline+ & positive impacts \\
\hline
\end{tabular}

Figure b. Synthetic representation of multi-criteria impacts of scenarios tested in the Sole fishery in the Bay of Biscay

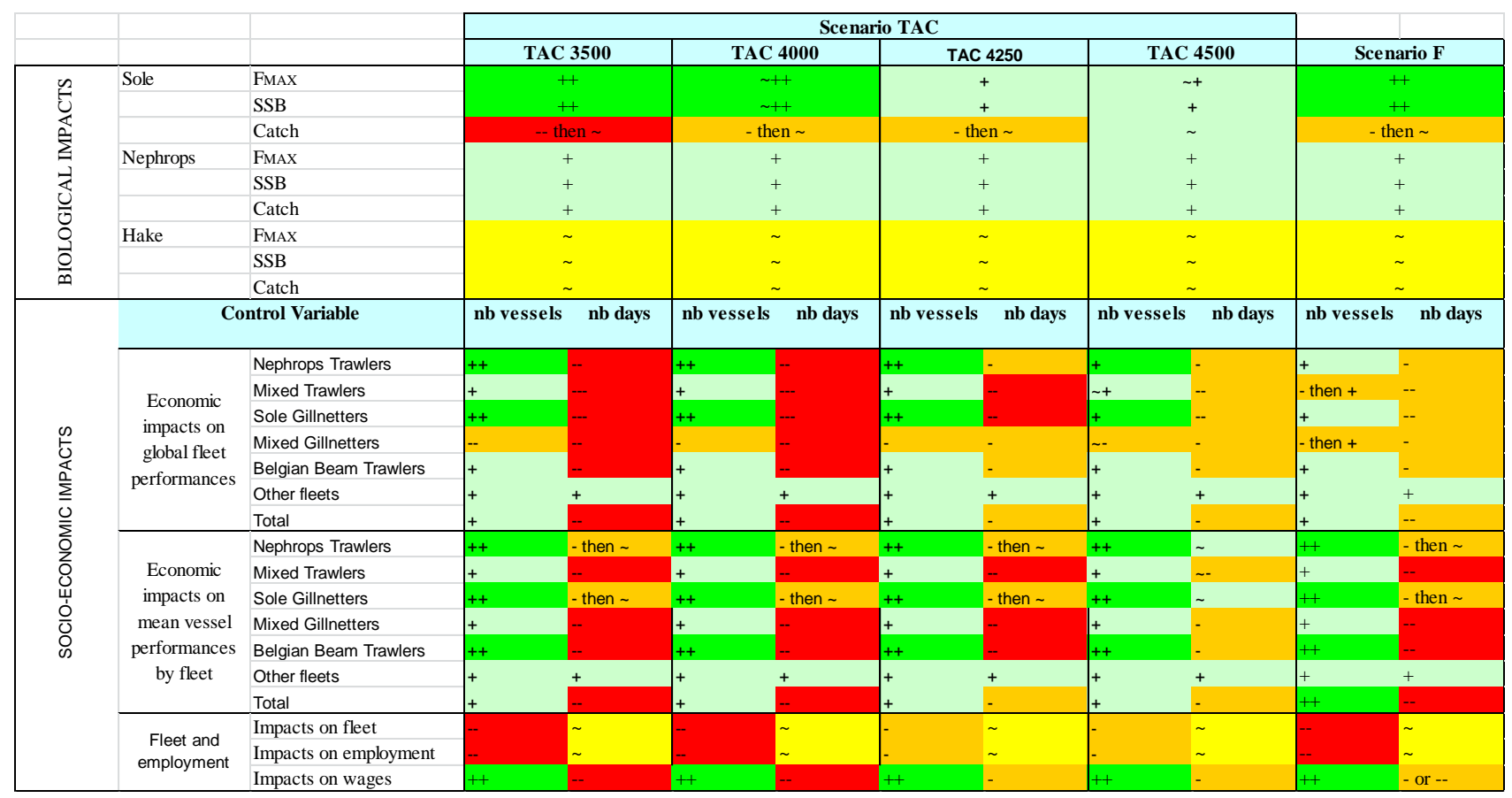


1154

1155

1156

1157

1158

1159

1160

1161

1162

1163

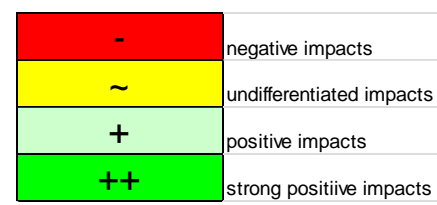

$++\quad$ strong positive impacts the gulf of Lion

strong negative impacts

negative impacts

undifferentiated or no impact

positive impacts

Figure c. Synthetic representation of multi-criteria impacts of scenarios tested in the Hake fishery in

\begin{tabular}{|c|c|c|c|c|c|}
\hline & & & \multicolumn{3}{|c|}{ Scenarios } \\
\hline \multirow{2}{*}{\multicolumn{3}{|c|}{ IMPACTS }} & A & \multicolumn{2}{|c|}{ B } \\
\hline & & & 1 month closure & $\begin{array}{c}\text { Decrease in nb of } \\
\text { vessels }\end{array}$ & $\begin{array}{c}\text { Decrease in } \\
\text { number of days at } \\
\text { sea }\end{array}$ \\
\hline \multirow{3}{*}{ 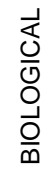 } & \multirow{3}{*}{ Hake } & $\mathrm{F} / \mathrm{Fmax}$ & $>1$ & \multicolumn{2}{|c|}{$\begin{array}{c}<1 \text { for }-15 \% \text { decrease per year } \\
\text { during } 4 \text { years }\end{array}$} \\
\hline & & $\begin{array}{l}\text { Spawning } \\
\text { Biomass }\end{array}$ & + & \multicolumn{2}{|c|}{++} \\
\hline & & Catches & + & \multicolumn{2}{|c|}{++} \\
\hline \multirow{10}{*}{ 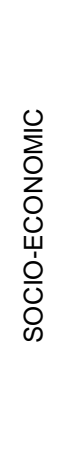 } & \multirow{4}{*}{ Total profit } & Netters & + & \multicolumn{2}{|c|}{+} \\
\hline & & Trawlers & - & \multicolumn{2}{|c|}{-} \\
\hline & & Other fleets & + & \multicolumn{2}{|c|}{+} \\
\hline & & Total & + or - & \multicolumn{2}{|c|}{+ or - } \\
\hline & \multirow{3}{*}{$\begin{array}{l}\text { Individual } \\
\text { profitability per } \\
\text { mean vessel }\end{array}$} & Netters & + & ++ & $7+$ \\
\hline & & Trawlers & - & ++ & - \\
\hline & & Other fleets & + & ++ & + \\
\hline & \multirow{3}{*}{$\begin{array}{l}\text { Fleet and } \\
\text { employment }\end{array}$} & $\mathrm{Nb}$ of vessels & $\sim$ & - & $\sim$ \\
\hline & & Employment & $\sim$ & - & $\sim$ \\
\hline & & Crew wages & + or - & + & + or - \\
\hline
\end{tabular}

1164 